\title{
Geomorphological correlation of the tectonically displaced Tejo River terraces (Gavião-Chamusca area, central Portugal) supported by luminescence dating
}

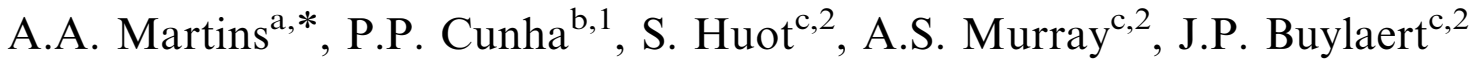 \\ ${ }^{a}$ Department de Geociências da Universidade de Évora, 7002-554 Évora, Portugal \\ ${ }^{\mathrm{b}}$ Department de Ciências da Terra, IMAR - Instituto do Mar, Universidade de Coimbra, Largo Marquês de Pombal, 3000-272 Coimbra, Portugal \\ ${ }^{\mathrm{c}}$ Nordic Laboratory for Luminescence Dating, Department of Earth Sciences, Aarhus University, Riso National Laboratory, DK-4000 Roskilde, Denmark
}

Available online 4 February 2009

\begin{abstract}
A suite of fluvial terraces (T1-T6, from top to bottom of the staircase) occur along a $\sim 70 \mathrm{~km}$ stretch of the Tejo River in central Portugal, between the small towns of Gavião and Chamusca. Terrace correlation was based upon the following: (a) aerial photograph analysis, geomorphological mapping and field topographic survey; (b) sedimentology of the terrace deposits, namely the maximum particle size, clast composition and lithofacies identification; and (c) K-feldspar infrared stimulated luminescence (IRSL) dating of the three lower terraces levels, as quartz optically stimulated (OSL) signal of the samples from these terraces was too close to saturation for all but two samples. The two upper terraces (T1 and T2) lack suitable materials for luminescence dating (e.g. sands/silts), but also their probable ages are beyond the upper range of the dating method. Faults affecting terraces and older deposits have been reported. The luminescence dating results suggest that some assignments of local terrace remnants were incorrect because of fault-related vertical displacements. The luminescence dating procedure also included a correction for anomalous fading in order to obtain more reliable estimates of the burial ages. The fading rate was identical for all samples, so for correlation of the terraces anomalous fading of the feldspar IRSL signal is considered not to be a significant problem. The T5 terrace has corrected ages of $\sim 42-99 \mathrm{ka}$, the T4 from $\sim 107$ to $222 \mathrm{ka}$ and the T3 terrace has a minimal age of $\sim 300 \mathrm{ka}$. Fluvial incision appears to have been principally controlled by regional uplift but also by localised movements along fault structures. Using the corrected ages of the T4 surface a time-averaged incision rate can be quantified as follows: (1) $\sim 0.29 \mathrm{~m} / \mathrm{ka}$ for reach III, (2) $\sim 0.53 \mathrm{~m} / \mathrm{ka}$ in the Chamusca area (east side on reach IV) and (3) $\sim 0.13 \mathrm{~m} / \mathrm{ka}$ in the Mato Miranda area (west side on reach IV, the less uplifted block according to the geomorphic framework).
\end{abstract}

(C) 2009 Elsevier Ltd and INQUA. All rights reserved.

\section{Introduction}

The Tejo River is the longest fluvial system of the Iberian Peninsula $(1007 \mathrm{~km})$, flowing from the Sierra de Albarracim $(1593 \mathrm{~m}$ altitude, in the Cordillera Iberica) and discharging to the Atlantic Ocean, near Lisboa (Fig. 1). Flowing to the southwest, the Tejo River crosses the Madrid Tertiary Basin (in Spain) and the Lower Tejo

\footnotetext{
*Corresponding author. Tel.: + 315266745300 ; fax: + 351266745397 .

E-mail addresses: aam@uevora.pt (A.A. Martins), pcunha@dct.uc.pt (P.P. Cunha), sebastien.huot@risoe.dk (S. Huot), andrew.murray@risoe.dk (A.S. Murray), jan-pieter.buylaert@risoe.dk (J.P. Buylaert).

${ }^{1}$ Tel.: + 351239860500 ; fax: + 351239860541 .

${ }^{2}$ Tel.: + 4546775979 ; fax: +4546774959 .
}

Tertiary Basin, in Portugal. These sedimentary basins are separated by an uplifted block of resistant rocks belonging to the Hesperian Massif, which was deformed during the Hercynian orogeny. Both the Madrid and the Lower Tejo Tertiary Basins are composed of smaller structural depressions, i.e. Campo Arañuelo Basin and Tietar valley in the west side of the Madrid Tertiary Basin and the Castelo Branco Basin in the northeast sector of the Lower Tejo Tertiary Basin. These sub-basins are separated by areas of basement, onto which the Tejo River is superimposed probably since the Pliocene (Cunha et al., 1993). This morphostructural framework created distinct morphological characteristics during the incision stage of the drainage: (1) reaches with valleys strongly incised into basement, either lacking fluvial terraces or showing rare terrace 


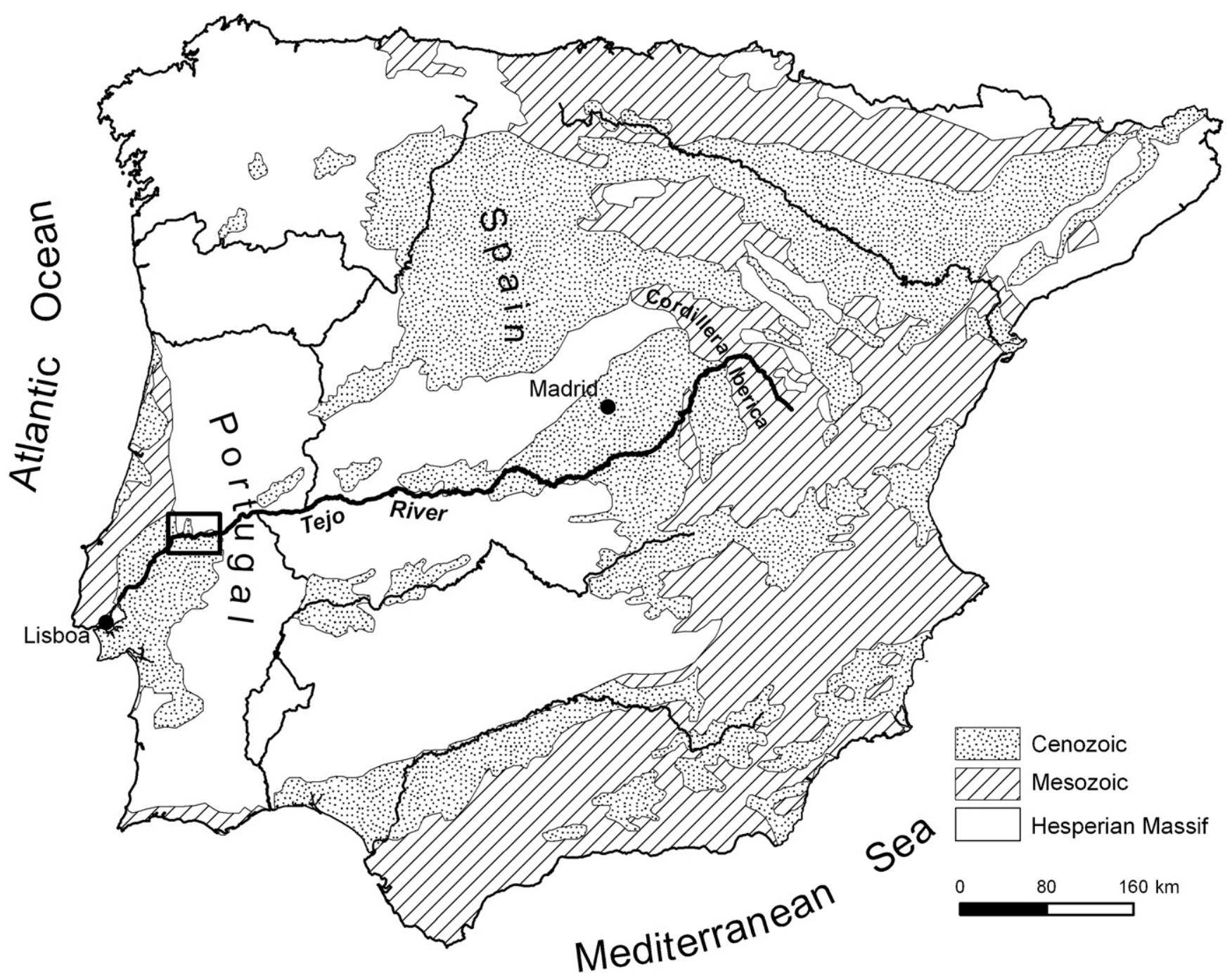

Fig. 1. Structural setting of the Iberian Peninsula (modified from Gutiérrez-Elorza, 1994).

development; (2) reaches with enlarged valleys, containing terrace staircases developed within Tertiary depressions. In the Portuguese sector, several principal reaches were identified, bound by the crossing of major faults (Fig. 2): reach I-from the Spanish border to Ródão town; reach II-bound by the Ponsul and Gavião faults (from Ródão to Gavião); reach III-between the Gavião and the Vila Nova da Barquinha faults (from Gavião to Arripiado); reach IV- downstream of the Vila Nova da Barquinha fault, until the estuary; reach $\mathrm{V}$-comprising the estuary.

This study deals with the establishment of a geomorphological correlation of fluvial terraces in reach III and part of reach IV, showing different geomorphological characteristics. Studies of 1/24,000 aerial orthophotos and of a digital elevation model (DEM) based upon a 1/25,000 topographic database were followed by detailed field surveying, mapping, outcrop description (terraces, faults, etc.) and laboratory characterisation of sediment samples (composition and grain size). Terrace correlation was based upon the following: (a) aerial photograph analysis, geomorphological mapping and field topographic survey; (b) sedimentology of the terrace deposits, namely the maximum particle size (MPS), clast composition and lithofacies identification; (c) luminescence dating of the three lower terraces levels.

Overall, the Portuguese Tejo reach III is a wide E-W trending valley with terraces, although locally a narrow valley forms where the river crosses basement heights between the fault-bound depressions of Alvega, Rossio and Tramagal (Fig. 3). Reach IV, with a NNE-SSW trend, comprises a very wide valley with well-developed terraces and a large Holocene alluvial plain (Fig. 4). Earlier studies described a staircase of four terraces (Zbyszewski, 1946, 1958). Martins (1999) identified an upper terrace level (T1), located just below the 'culminant sedimentary surface' (CSS) of the basin (Figs. 3 and 5).

Within tectonically active regions it is important to assess the role of active faulting and regional uplift for river terrace development and drainage evolution. During longterm drainage evolution, uplift and associated base-level changes can control the genesis of the fluvial terraces (e.g. Maddy, 1997; Maddy et al., 2000). In order to clarify the 


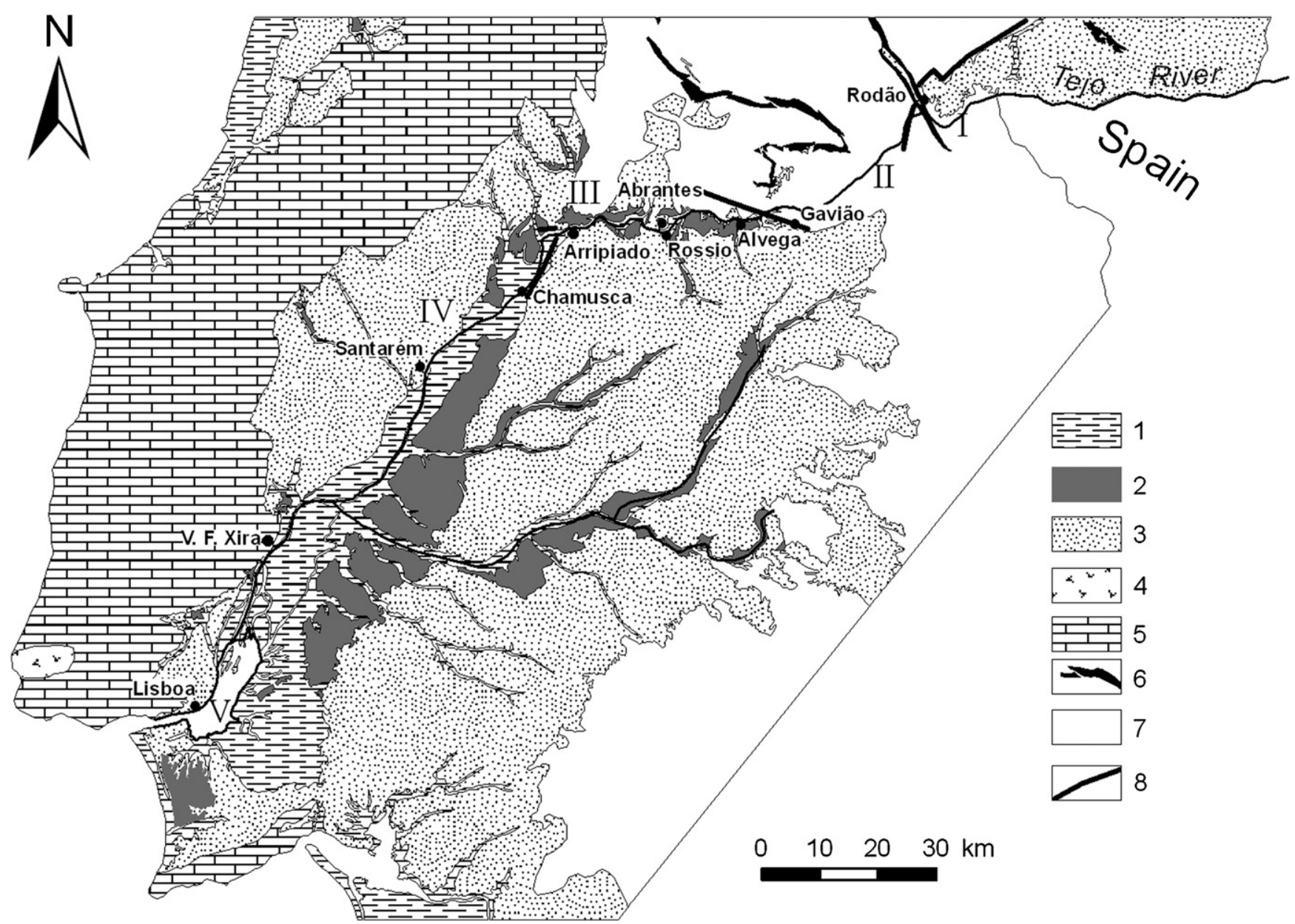

Fig. 2. Simplified geological map of the Lower Tejo Tertiary Basin. 1—alluvium (Holocene); 2 - terraces (Pleistocene to Gelasian); 3 -Tertiary; 4 -Sintra igneous massif; 5-Mesozoic; 6 -quartzites (Ordovician); 7-basement (Palaeozoic); 8-faults crossed by different Tejo reaches. The main Portuguese reaches in which the Tejo River can be divided are also represented: I — from the Spanish border to Vila Velha de Ródão; II—from Vila Velha de Ródão to Gavião; III - from Gavião to Arripiado; IV—-from Arripiado to Vila Franca de Xira; V—from Vila Franca de Xira to the Atlantic shoreline.

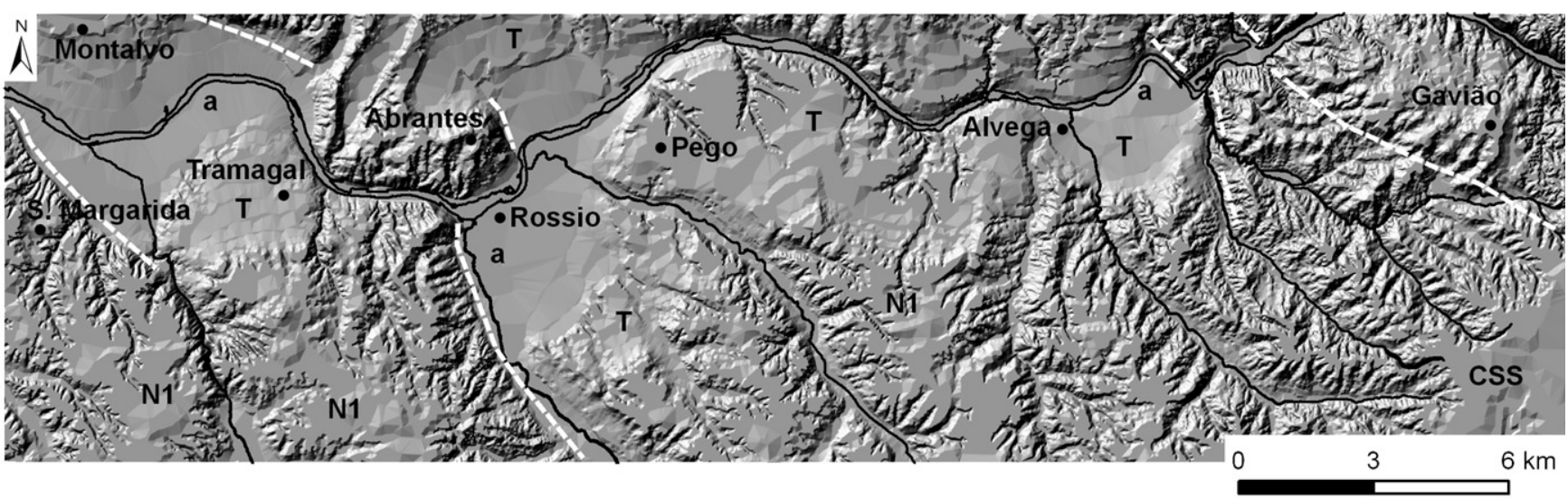

Fig. 3. Digital elevation model (DEM) comprising a part of the Tejo reach III. Note the Alvega, Rossio and Tramagal depressions and some main faults (white dashed lines). CSS — culminant sedimentary surface; N1—Mora-Lamarosa level; T—terraces; a—alluvium.

importance of regional uplift and to identify active tectonic faulting, terrace correlation should be supported by numerical dating of samples collected at the base and top of each terrace deposit.
Numerical dating of river terraces can be limited by the absence of suitable materials or because part of a fluvial terrace is buried by later sediment (e.g. slope material). Caution should be used to correlate between fluvial 


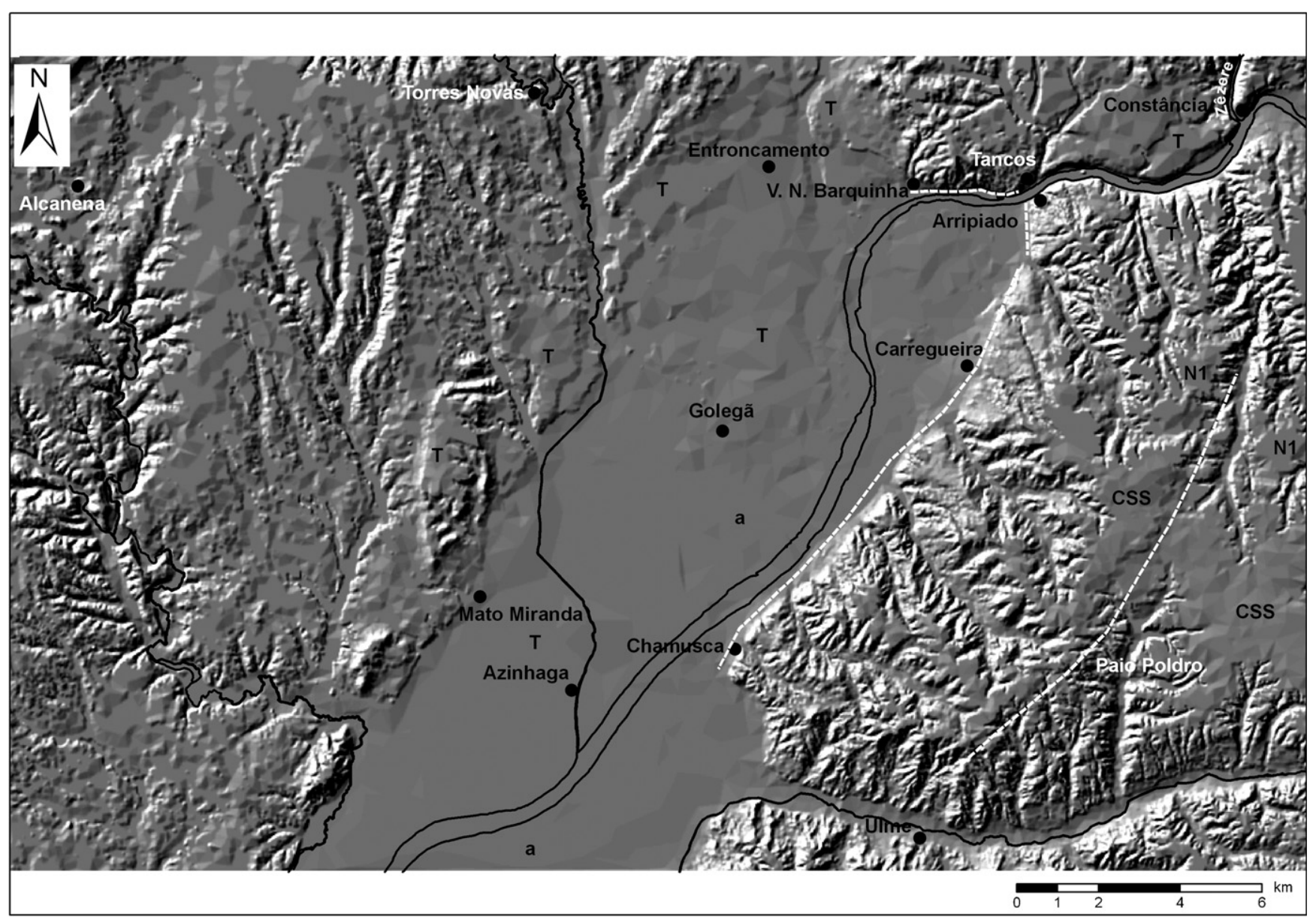

Fig. 4. DEM of the upstream part of Tejo reach IV. Note the E-W scarp of Vila Nova da Barquinha at the transition of reach III to reach IV and the NNE-SSW Arripiado-Chamusca scarp. The Tejo flows in a wide alluvial plain, in this figure indistinguishable from the lower terrace at Azinhaga. At Mato Miranda area, remnants of the upper terrace form a landscape of residual "mesas" (see Fig. 3 for legend).

terraces, even if based upon numerical ages. Datable sediment located above a fluvial strath surface provides only a minimum age for the time of strath formation (Merritts et al., 1994). Equally, some delay exists, from downstream to upstream, in the migration of knickpoints or fluvial strath abandonment/incision, which collectively produce a complex record of spatially and temporally variable fluvial geomorphic surfaces (Seidl and Dietrich, 1992; Merritts et al., 1994).

Until now, a limited number of dates have been obtained for the terraces of the Portuguese part of the Tejo River, derived from U-series, thermoluminescence (TL) and optically stimulated luminescence (OSL) techniques (Raposo, 1995; Raposo and Cardoso, 1998; Cunha et al., 2008). This is the first time that terrace ages within reach III of the Tejo River are reported. However, radionuclide analysis revealed an unusually high dose rates in the sediments $(\sim 4 \mathrm{~Gy} / \mathrm{ka})$ and this prevented the routine application of quartz OSL dating; so, for this study IRSL dating using $\mathrm{K}$-feldspar was applied.

The height of a fluvial terrace surface above the modern river profile (assuming negligible surface erosion) can be used to calculate the long-term bedrock incision rate. This in turn can be used as a proxy for crustal uplift (Bridgland, 2000; Maddy et al., 2000), but taking into account the uncertainty that a steady state river long profile after the uplift may not have been fully reached. Fluvial terraces are geomorphic markers that also record deformation associated with active faults (e.g. Merritts et al., 1994; Burbank et al., 1996; Burbank and Anderson, 2001). Movement along individual faults may subtract or add up to the epeirogenic crustal uplift.

The study area lies in an intraplate continental setting of moderate compression, resulting from convergence between Africa and Iberia along the Azores-Gibraltar Fracture Zone and Atlantic ridge-push forces (Srivastava et al., 1990; Ribeiro et al., 1996). The magnitude of vertical fault displacements during the Pliocene to Pleistocene suggests that the tectonic processes controlling topographic development are ongoing (Cabral, 1995; Cabral et al., 2004). Thus, tectonic uplift exerts a first-order control on the present relief configuration of Iberia, characterized by a succession of highs and lows that trend normal to the present-day intraplate compressional stress trajectories (Cloetingh et al., 2005). This study area is a natural laboratory suitable for investigating the fluvial incision 
response to major active faults linked to the crustal uplift of Iberia and its ongoing geodynamics.

\section{Geomorphological and geological setting}

On the Portuguese mainland, the Tejo River flows mainly through soft sediments of the Lower Tejo Tertiary Basin, a NE-SW elongated fault-bounded basin. Basin formation started during the middle Eocene (Carvalho et al., 1983-1985; Azevedo, 1991; Cunha, 1992; Galdeano, 2000). Sedimentation occurred mainly during the Miocene, but major palaeogeographic changes with associated drainage re-organisations occurred during the late Tortonian to Pliocene (Cunha, 1992), during which elevated compression resulted in tectonic inversion of Mesozoic extensional structures (Ribeiro et al., 1990; Rasmussen et al., 1998).

The thickness of the Tertiary succession is variable, ranging from $\sim 100$ to $300 \mathrm{~m}$, in the study area, but rapidly thinning towards the northern and eastern basin margins. To the southwest, near Lisboa, sediments can reach a thickness of up to $2000 \mathrm{~m}$ (Mendes-Victor et al., 1980; Rasmussen et al., 1998). The Tertiary infill is mostly continental, except near Lisboa, where several marine incursions occurred during the Miocene and Pliocene (Antunes and Pais, 1993; Barbosa, 1995). The main lithologies consist of alluvial fan arkoses and conglomerates (Paleogene), fluvial arkoses and silts, passing upwards into lacustrine carbonates (Aquitanian to lower Tortonian) and a younger group of formations (probable upper
Tortonian to Piacenzian) mainly comprising poorly sorted siliciclastics. This younger group represents the sedimentary response to the uplift phases of the Portuguese Central Range (Cunha et al., 1993; Barbosa, 1995; Barbosa and Reis, 1996).

During the late Tortonian to Zanclean the Lower Tejo Tertiary Basin was endorheic, with alluvial fan sedimentation occurring along tectonic fault scarps. An exorheic drainage system was only developed during the transition to more humid conditions in the Piacenzian, when the ancestral Tejo became a gravelly braided river (Cunha et al., 1993). The sedimentary unit of this braided river system, named Serra de Almeirim Conglomerates in the study area (Barbosa and Reis, 1989; Barbosa, 1995), marks the culmination of sedimentary basin infilling, part of which also covered ridges of quartzite along the basin margin.

According to Cunha (1996), the evolution of the drainage network from a Piacenzian wide alluvial plain to an entrenched fluvial system started probably during the Gelasian (Late Pliocene). During the incision stage, ridges of quartzite basement were crossed by the Tejo and tributaries, in a mechanism of superposition leading to the excavation of deep valleys and development of terrace staircases (Cunha et al., 2005). In the study area the relief of the Lower Tejo Tertiary Basin is dominated by two plateaus (Fig. 5): (a) the culminant sedimentary surface of the basin, ca. 190-280 $\mathrm{m}$ above sea level (a.s.1.), corresponding to the top of the Serra de Almeirim Conglomerates; and (b) an extensive erosional surface (the MoraLamarosa level-N1), at about $140-180 \mathrm{~m}$ a.s.l., related to

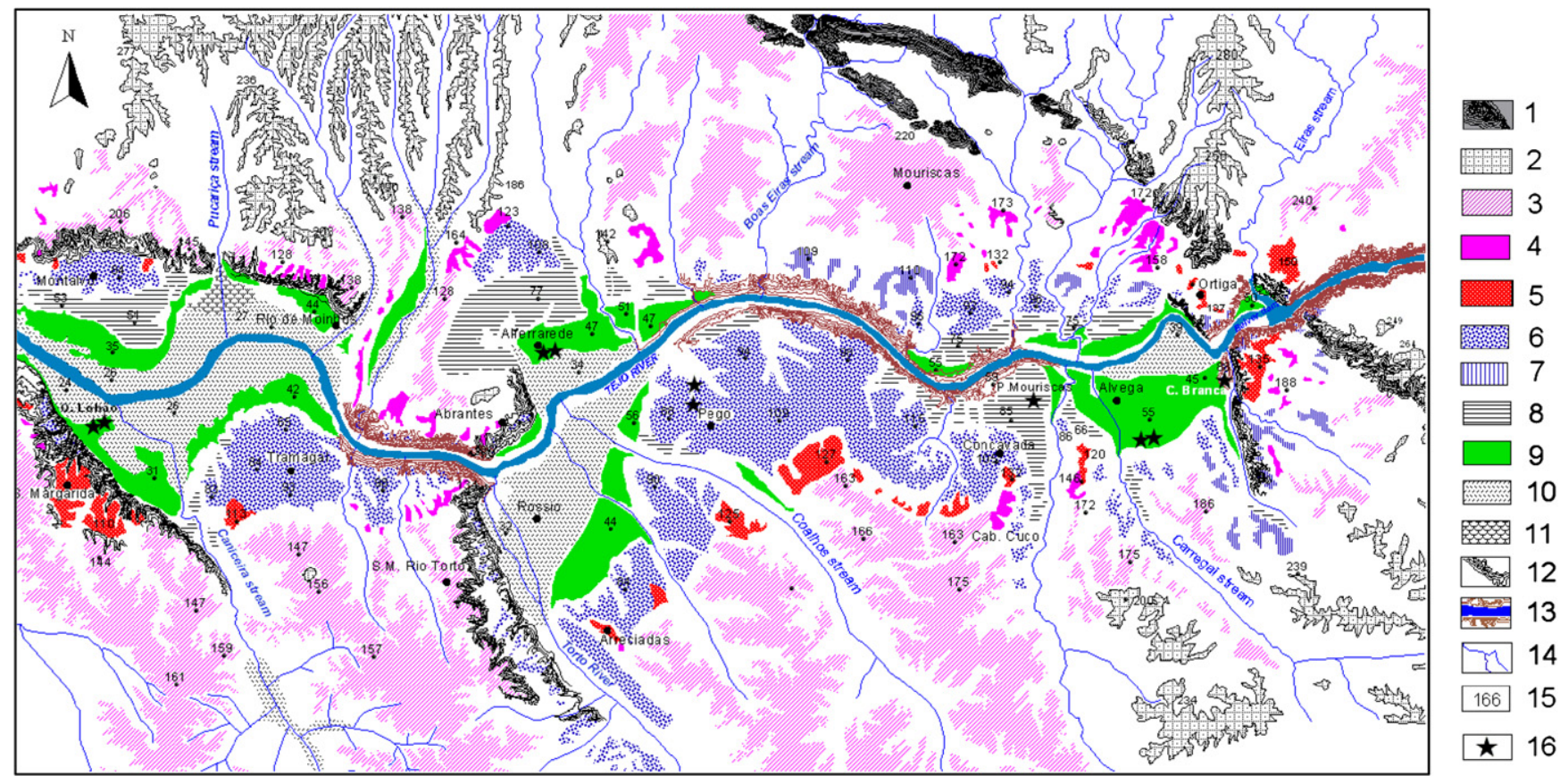

Fig. 5. Geomorphological map of the Abrantes area, showing the eastern part of the Tejo reach III. 1—quartzite ridge; 2 - culminant surface of the sedimentary basin; 3-Mora-Lamarosa level (erosion surface N1); 4-T1 terrace (fill); 5-T2 terrace (fill or strath terrace); 6-T3 terrace (fill); 7 - T3 terrace (strath); 8-T4 terrace (fill); 9-T5 terrace (fill); 10 - alluvial plain; 11-alluvial fan; 12 - fault scarp; 13 - entrenched valley of the Tejo River; 14 channel network; 15-altitude (m); 16-sampled site. 


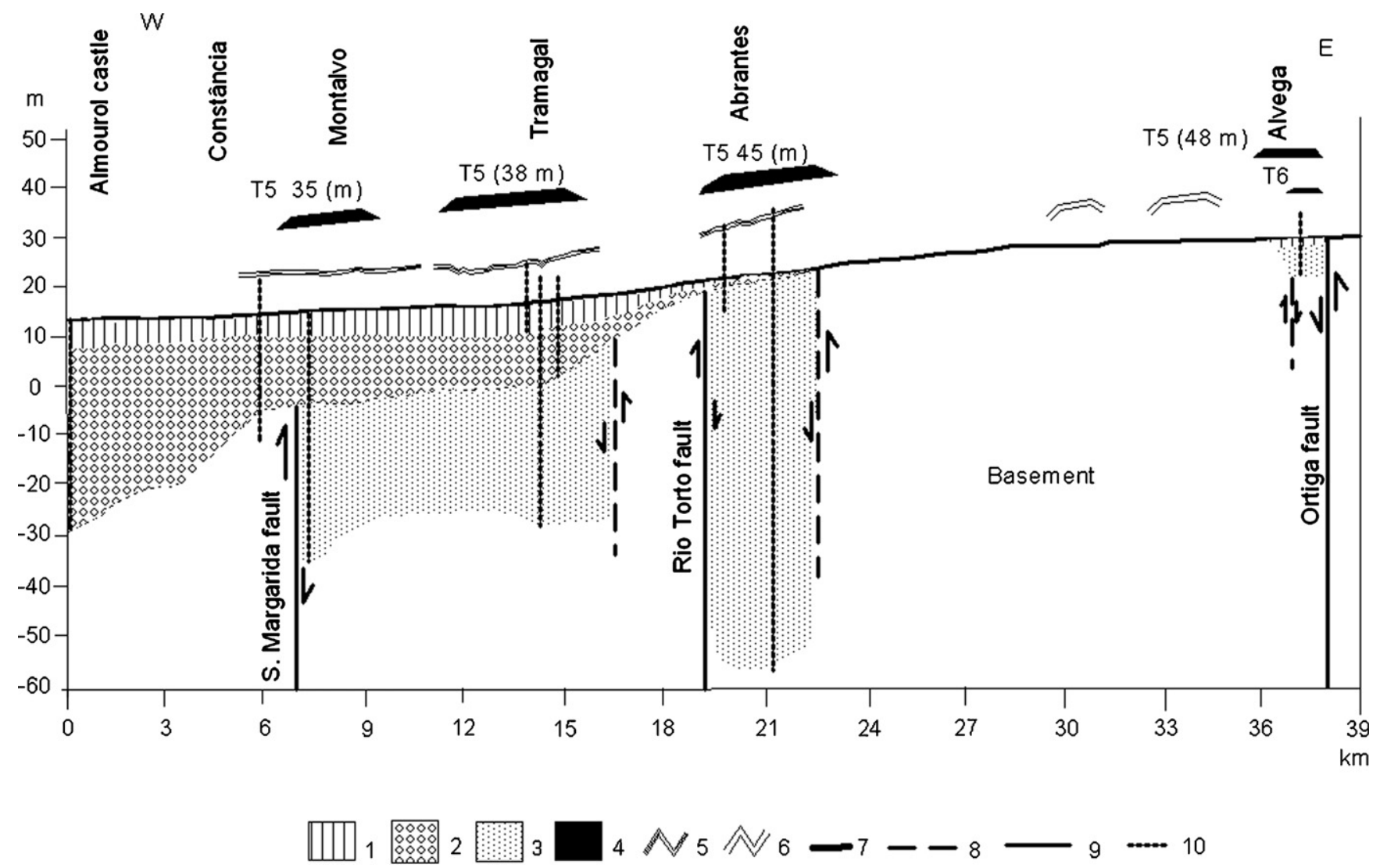

Fig. 6. Projected longitudinal profile of the Tejo River, between Alvega and the Almourol castle. Note the Holocene wedge of sediments downstream of Abrantes. On the Tramagal, Rossio and Alvega tectonic depressions, the Tertiary infill was not completely eroded during the incision stage prior to Holocene aggradation. The modern alluvial plain, at about 8 to $10 \mathrm{~m}$ above the river bed, is beginning to form a new and very young terrace. 1 -muddy sands and clays; 2-pebbly sands; 3-Tertiary sediments; 4-T5 terrace; 5-floodplain; 6-young strath terrace above the talwegue (T6); 7-river bed; 8probable fault; 9-fault; 10 -well.

the first regional episode of fluvial incision (Martins and Barbosa, 1992; Martins, 1999).

Below the CSS, a staircase of six terraces (named T1-T6 from top to bottom) is recorded in the fault-bound depressions of Alvega, Rossio and Tramagal, where the Tejo River was able to enlarge its valley in soft Tertiary sediments (Fig. 5). The T1 occurs in the same general geomorphic level as the $\mathrm{N} 1$, but close to the trunk channel. Outside of the depressions, the river cut a narrow valley into hard Palaeozoic basement and the two lower terraces are absent or poorly represented. Field surveys indicate that away from bounding fault structures, the Tejo flowed over Tertiary sediments. This occurred until the development of the T3 terrace; the Tejo began to down cut into the resistant basement bedrock during a new incision episode that later gave rise to the $\mathrm{T} 4$ terrace.

In reach III a Holocene eustacy-driven depositional wedge is $\sim 40 \mathrm{~m}$ thick at Almourol castle ( $5 \mathrm{~km}$ downstream of Constância), $\sim 20 \mathrm{~m}$ between Montalvo and Tramagal and tapers to zero near Abrantes (Fig. 6). Upstream of Abrantes, the valley floor is cut into resistant basement. This indicates that reach III lies in the estuarine headward limit of the Holocene transgression and that backfilling related to the eustatic rise does not reach any further upstream. The modern alluvial plain is $25 \mathrm{~m}$ a.s. 1. ( $8 \mathrm{~m}$ above the river bed-a.r.b.) at the Tramagal fault-bound depression (Fig. 6). Locally, the alluvial river plain forms a very young terrace (T6) inundated during major floods. Downstream, at Chamusca (reach IV), channel incision into the modern alluvial plain is $\sim 4 \mathrm{~m}$ (channel at $14 \mathrm{~m}$ and alluvial plain at $18 \mathrm{~m}$ a.s.1.). This indicates an ongoing tendency for the river to incise, but it is unknown whether this is natural or anthropogenic. Notwithstanding this recent incision, some tributaries (e.g. the Ulme stream: Fig. 4) flow in the alluvial plain, parallel to the Tejo channel, and their confluences are located far downstream.

\section{Geomorphological characteristics of the study area}

In reach II, the modern Tejo occupies an uplifted basement block (Fig. 7) where the bounding fault has displaced the basin CSS by $\sim 30 \mathrm{~m}$ (Martins, 1999). This reach lacks terrace development and the modern Tejo channel is ca. $230 \mathrm{~m}$ below the CSS. Transverse valley cross-sections at Gavião indicate a change in valley shape, from wide and shallow to deep and narrow, suggesting an increase in fluvial incision over time. 


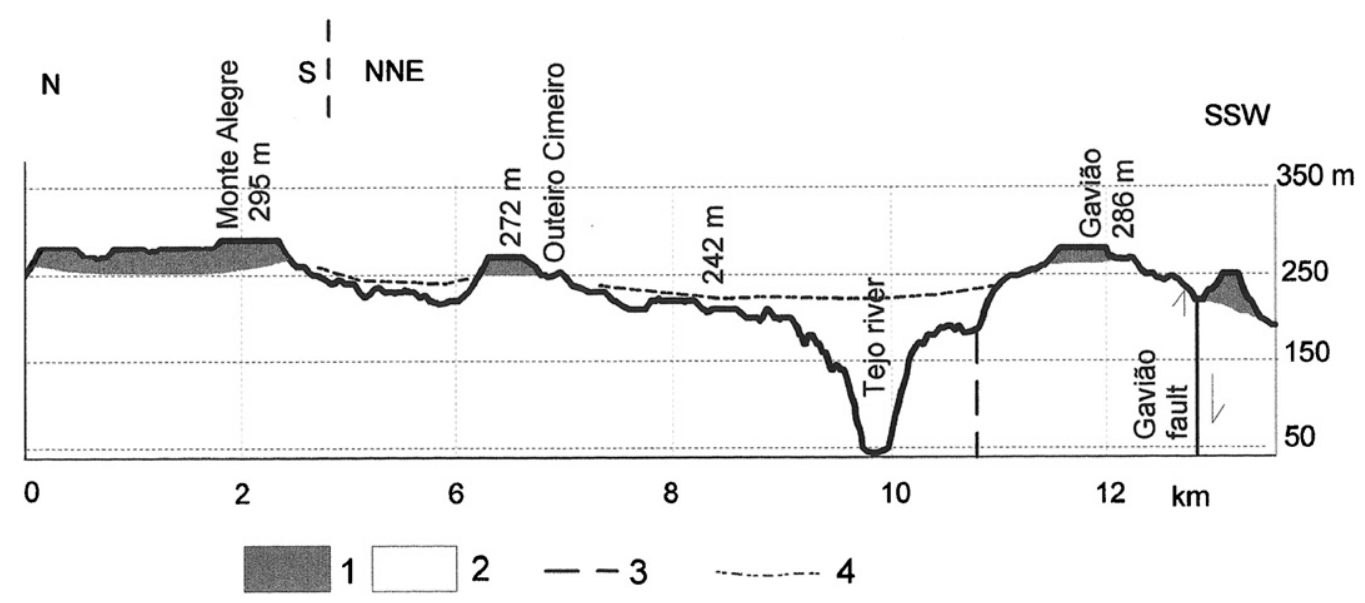

Fig. 7. Transverse profile of the Tejo reach II, near Gavião. Notice the upper surface of the sedimentary basin at Monte Alegre (295m) and Gavião $(286 \mathrm{~m})$, the Mora-Lamarosa level (ca. $242 \mathrm{~m}$ ) and the more recent strong incision of the Tejo River. The Gavião fault displaces the upper surface of the basin by ca. $30 \mathrm{~m}$. 1-Tertiary sediments; 2-Palaeozoic basement; 3-probable fault; 4-Mora-Lamarosa level (erosion surface).

Immediately downstream of the Gavião fault, the valley morphology changes (reach III). Here, the incision of the Tejo from the CSS is only $175 \mathrm{~m}$ and the river has developed extensive terrace flights (Figs. 3 and 5). The Gavião fault has also controlled the Tertiary sedimentation whereby on the uplifted block the Tertiary sediments are $\sim 10-30 \mathrm{~m}$ thick, whilst reaching more than $100 \mathrm{~m}$ in the subsident block.

In reach III the Tejo River is superimposed on the uplifted basement blocks, which determinate entrenched reaches in the basement blocks and valley enlargements in the fault-bound depressions (i.e. between Rossio and Tramagal). Although the Tejo valley appears to be passively controlled by the lithology of the river bed, the geometry of the main channel indicates adjustments to tectonics. For example, in the Alvega depression the river changes its direction sharply towards the northwest, following the Ortiga fault (Figs. 3 and 5). Within the Tramagal depression, the Tejo switches first to the northwest against the Montalvo fault scarp, and afterwards to the southwest along the Santa Margarida (Figs. 3 and 5).

Minor adjustments of the drainage were identified on the uplifted basement block between Constância and Arripiado (Fig. 8). Here, the Tejo has excavated a narrow valley and the T4 and T5 terraces are scarcely present. At Constância, a small stream has captured the Zêzere River near the mouth, leaving an old abandoned valley entrenched in the T3 surface. This abandoned valley and the neighbouring T4 terrace of the Zêzere and Tejo Rivers are at a similar altitude, suggesting a similar age.

Reach IV begins when the Tejo enters the Lower Tejo fault zone, where the valley trend is associated with NNESSW and E-W valley bounding faults (Fig. 4). The main channel, after flowing $2 \mathrm{~km}$ parallel to the Vila Nova da Barquinha fault (E-W), turns to follow the ArripiadoChamusca fault scarp (NNE-SSW) (Figs. 4 and 8). The terrace staircase on the western side of the Tejo valley has more extensive terraces with less elevation than the terrace staircase on the eastern side. Another morphotectonic feature occurs in the Chamusca area where an E-W trending fault, coinciding with the Ulme stream, has tilted the culminant surface to the northeast (Fig. 8) resulting in an inversion of the original depositional slope. On the eastern side of the uplifted block, the Paio Poldro fault (trending N-S) has displaced the CSS by $\sim 30 \mathrm{~m}$ (at $190 \mathrm{~m}$ a.s.l. to the west and $150-160 \mathrm{~m}$ to the east; Martins, 1999).

\section{Tejo River terrace staircases}

\subsection{Terraces of reach III}

In the Abrantes area, the Tejo terrace staircase (Fig. 5) can be characterized as follows. On the south side of the Tejo, the T1 terrace is $\sim 168 \mathrm{~m}$ a.s.l. ( $+140 \mathrm{~m}$, a.r.b.). The $\mathrm{T} 1$ deposits are up to $5 \mathrm{~m}$ thick and consist of conglomerates with clasts of quartzite $(70 \%)$ and quartz $(30 \%)$, with a maximum particle size of $24 \mathrm{~cm}$. The clast composition of the Serra de Almeirim Conglomerates is dominated by quartzite $(80 \%)$. The provenance of the terrace deposits suggests reworking from the Serra de Almeirim Conglomerates and quartz-rich Miocene units. The $\mathrm{T} 2$ terrace is represented by small treads at about $132 \mathrm{~m}$ a.s.l. $(+108 \mathrm{~m}$ a.r.b.) near Concavada. Remnants of T2 are discontinuous over reach III. The $5-10 \mathrm{~m}$ thick sediment is composed of a clast-supported conglomerate (MPS $\sim 24 \mathrm{~cm}$ ). The T3 terrace is extensively continuous down-valley with a tread at $98 \mathrm{~m}$ a.s.1. ( $+73 \mathrm{~m}$ a.r.b.) (Fig. 5). Terrace deposits typically comprise 10-12 m thick clast-supported conglomerates, intercalated with lenses of sandstones. Within the conglomerates, the MPS is commonly $\sim 25 \mathrm{~cm}$. The T4 terrace lies at $85 \mathrm{~m}$ a.s. $1 .(+63 \mathrm{~m}$ a.r.b.) and is represented by a conglomerate up to $\sim 8 \mathrm{~m}$ thick, with a MPS of $\sim 26 \mathrm{~cm}$. The T5 terrace is $50 \mathrm{~m}$ a.s.l. $(+28 \mathrm{~m}$ a.r.b.) at Alvega where it comprises a $2 \mathrm{~m}$ thick basal clast-supported conglomerate with a MPS of $15 \mathrm{~cm}$, overlain by $4 \mathrm{~m}$ of sands and mudstones. The lower edge of 


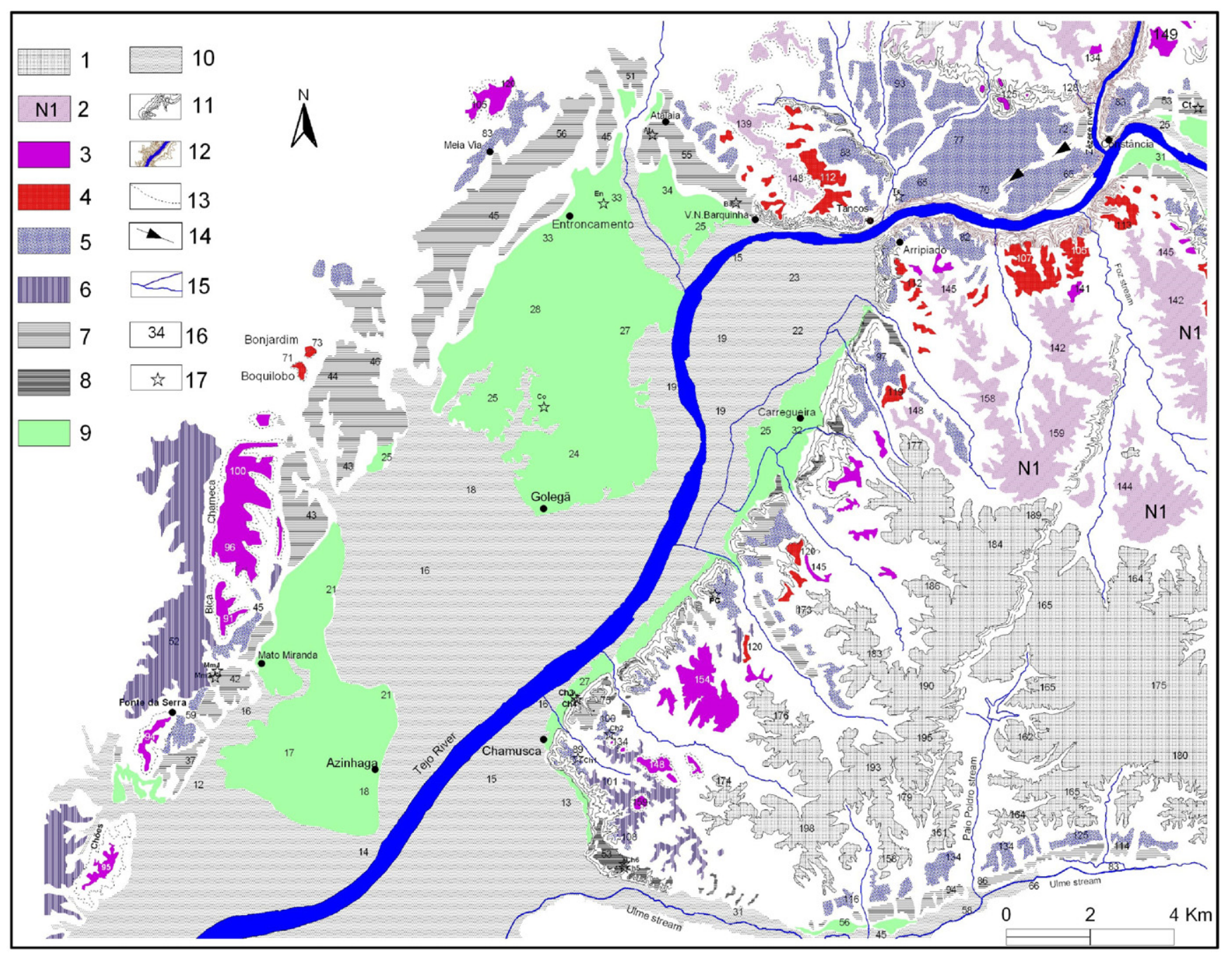

Fig. 8. Geomorphological map of the Chamusca area, comprising the upstream part of the Tejo reach IV (SW-NE) and part of reach III (W-E). 1culminant surface of the Tertiary basin; 2-Mora-Lamarosa level (N1 erosion surface); 3-T1 terrace; $4-\mathrm{T} 2$ terrace; 5- T3 terrace; 6-N3 erosion surface (that links with the T3 terrace); 7-T4 terrace; 8-T4a terrace; 9-T5 terrace; 10 - alluvial plain; 11-fault scarp; 12 - entrenched valley; 13-foot slope of a mesa relief; 14 -abandoned valley; 15-channel network; 16-altitude (m); 17—sampled site (Ct-Constância; T-Tancos; Ba-V.N. Barquinha; En-Entroncamento; Co-Courelas J. Mendes; PG-Pinheiro Grande; Ch1—Chamusca1; Ch2-Chamusca2; Ch3-Chamusca3; Ch4Chamusca4; Ch5 - Chamusca5; Ch6 - Chamusca6; Mm1-Mato Miranda1; Mm2-Mato Miranda2).

the basal conglomerate is buried by modern alluvium. In reach III, the T3 terrace is extensive, enabling its usage as a regional geomorphic marker to assess the positions of other terrace levels. The T3 terrace appears to document a long period of fluvial equilibrium, during which the Tejo was able to cut a strath terrace onto the resistant basement bedrock upstream and downstream of the fault-bound depressions. The T4 and T5 terraces only exist within the fault-bounded depressions at Alvega, Rossio and Tramagal. Within these areas the river was able to enlarge its valley into the soft Tertiary infill, creating hydraulic conditions favouring aggradation. Between the depressions, the river cut a narrow valley into the hard basement bedrock which functioned as a local base level to the upstream reaches. The fact that limited terraces have developed within the narrow valleys in uplifted blocks between the tectonic depressions indicates focussed vertical erosion. In contrast, terraces within the tectonic depressions occupy broader valley forms whereby terraces appear to have a greater degree of development along the southern valley margin (Fig. 5). This asymmetric occurrence could suggest uplift along the northern valley margin (Martins, 1999).

\subsection{Terraces of reach $I V$}

\subsubsection{General characteristics}

Terrace staircases within reach III can be confidently correlated at similar altitudes across its valley. However, within reach IV the terrace staircase on the eastern valley margin occurs at a higher altitude than the staircase on the western margin. Five terrace levels step down towards the modern alluvial plain (Fig. 8). The CSS is not preserved in the western margin. 


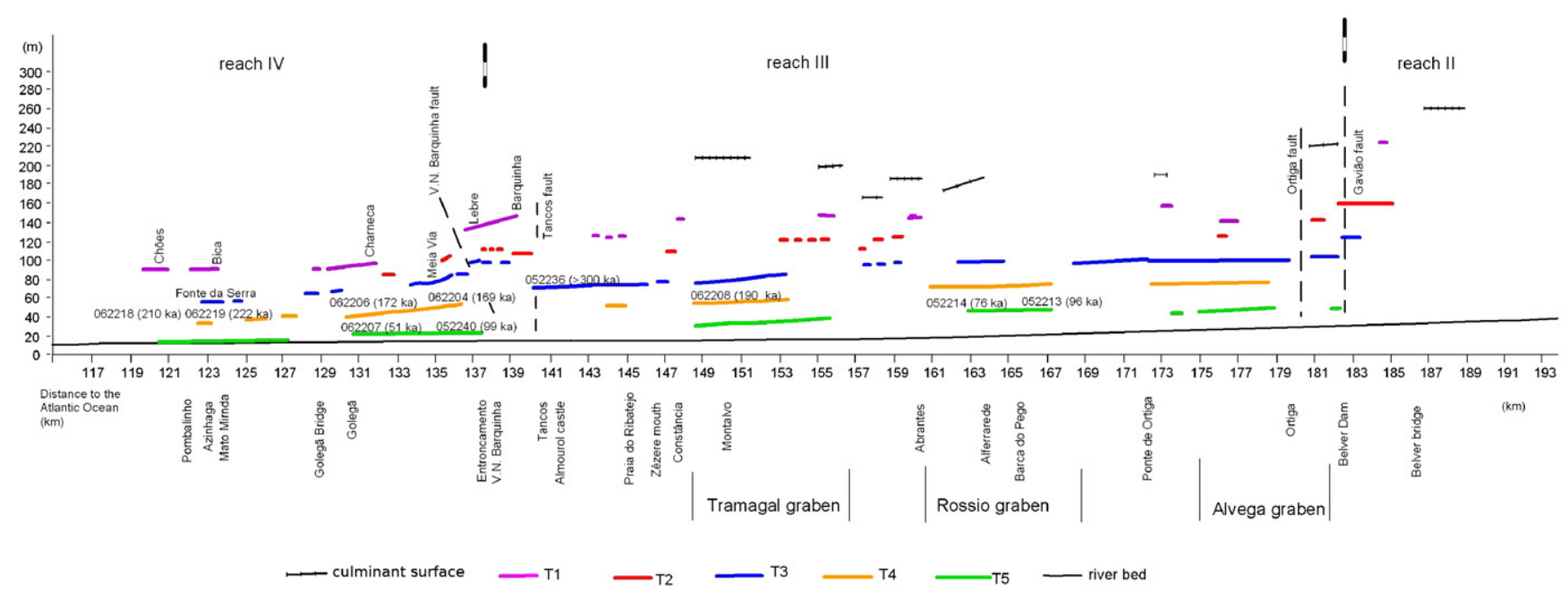

Fig. 9. Longitudinal profile of the Tejo River and west side terraces, including reach III and the transition to the adjacent reaches. The distance upstream from the Atlantic shoreline is indicated (horizontal scale). The vertical displacement of the terraces induced by the Gavião fault and the terrace convergence downstream of the Vila Nova da Barquinha fault can be seen.

\subsubsection{Western side of reach $I V$}

The highest terrace level was ascribed to $\mathrm{T} 1$ and is locally represented by remnants at Charneca $(100-96 \mathrm{~m})$, Bica $(91 \mathrm{~m})$ and Chões $(94 \mathrm{~m})$ (Figs. 8 and 9). T2 is represented by the Boquilobo hill, $71 \mathrm{~m}$ a.s.l.

The T3 terrace occurs at Meia Via (96 m a.s.1.) and at Fonte da Serra ( $59 \mathrm{~m}$ a.s.1.). Along the western side of reach $\mathrm{IV}$, the T1 and the T2 terrace remnants collectively form resistant conglomerate hills. These create an inverted landscape of residual mesas that stand out from the weaker underlying Miocene sediments.

The T4 terrace is extensive, occurring at an elevation of $55 \mathrm{~m}$ a.s.l. near Atalaia but becoming progressively lower downstream to $42-37 \mathrm{~m}$ in the Mato Miranda to Fonte da Serra area (Fig. 8). This terrace comprises basal gravels overlain by sands and silts. OSL samples were collected from the sands and silts in the upper part of the terrace at a location west of Mato Miranda (062218 and 062219) and at Vila Nova da Barquinha (062204) and Atalaia (062206). In situ archaeological artefacts were found near Atalaia, in basal and topmost parts of the terrace deposits (Fernandez, 1997; Grimaldi et al., 1997). The majority of artefacts was made of quartzite and has been attributed to the Lower and Middle Palaeolithic (Middle and Upper Pleistocene) (Fernandez, 1997; Grimaldi et al., 1997).

The T5 terrace is the most extensive level within reach IV, occurring near Entroncamento (33 $\mathrm{m}$ a.s.1.) but becoming progressively lower downstream towards Azinhaga (18 $\mathrm{m}$ a.s.1.) (Fig. 8). At Mato Miranda, a narrow NNE-SSW strip of T5 occurs at $24 \mathrm{~m}$ a.s.l., and is considered to be displaced by a NNE-SSW fault. This hypothesis will be discussed below and is supported by OSL dating. At Azinhaga, a $3 \mathrm{~m}$ deep trench into the T5 terrace surface exposed coarse sands interbedded with $0.5 \mathrm{~m}$ thick conglomeratic lenses with a MPS of $5 \mathrm{~cm}$; these characteristics suggest infilling of a fluvial channel. At Golegã, a $3 \mathrm{~m}$ deep trench revealed massive medium sands and silts which are attributed to an overbank, floodplain style of sedimentation. The terrace surface is scattered with Holocene artefacts, but some Palaeolithic instruments have also been found, possibly reworked from the T4 terrace (Grimaldi et al., 1997). The alluvial plain is up to $6 \mathrm{~km}$ wide with elevations that vary between 19 and $12 \mathrm{~m}$ a.s.l.

\subsubsection{Eastern side of reach $I V$}

Along the eastern valley side within reach IV river terraces occur between Arripiado to Chamusca (Figs. 8 and 10). The following paragraphs describe the welldeveloped terrace staircase within the Chamusca area.

Discontinuous remnants of the $\mathrm{T} 1$ and $\mathrm{T} 2$ terraces lie at ca. 148 and $120 \mathrm{~m}$ a.s.1., respectively. In contrast to this, the T3 terrace forms an extensive plateau-like feature whose top surface grades down from $108 \mathrm{~m}$ a.s.l. along its outer valley edge to $89 \mathrm{~m}$ a.s.l. along its inner, central valley edge. $\mathrm{T} 1-\mathrm{T} 3$ terraces have a clear morphological expression as fluvial terrace landforms but lack good exposures through their sediments. However, abundant rounded boulders, scattered on their surfaces, suggest a predominantly conglomeratic character for the terrace deposits.

The T4 terrace can be identified down slope along the margins of the T3 plateau-like level, at $75 \mathrm{~m}$ a.s.l. Terrace sediments comprise $5 \mathrm{~m}$ thick fining upwards accumulations of clast-supported gravels that are interbedded with sands. These are interpreted as aggrading braided river bar forms (Fig. 11). A similar sedimentary succession is exposed for T4 in the Mato Miranda area on the opposite, western side of the valley (Section 4.2.2). A local duplication of the T4 terrace, here named T4a, is identified at $53 \mathrm{~m}$ a.s.1. near the Ulme stream (southeast of Chamusca). This duplication is attributed to the block uplift between the Arripiado-Chamusca and the Paio Poldro faults (Figs. 4 and 8).

The $\mathrm{T} 5$ terrace forms a narrow strip along the base of the Chamusca scarp, at $27 \mathrm{~m}$ a.s.l., where it consists of a 


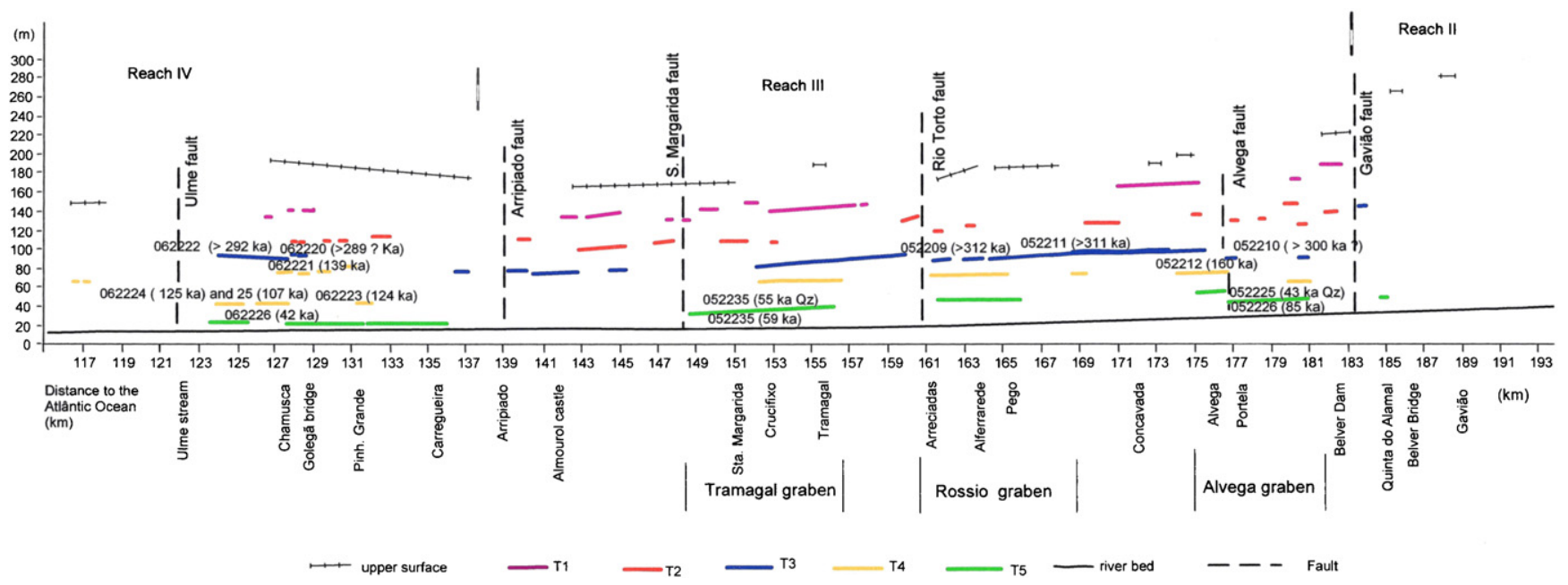

Fig. 10. Longitudinal profile of the Tejo River and east side terraces, including reach III and the transition to adjacent reaches. Note the upstream convergence of the terraces and the tectonic duplication of the T4 terrace in the Chamusca area (reach IV).

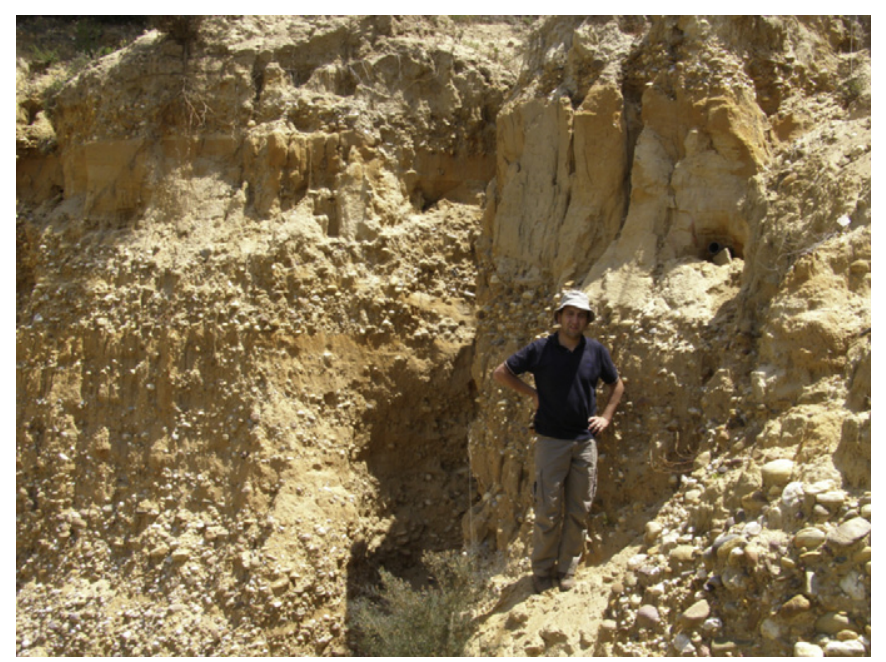

Fig. 11. Picture of the terrace T4 in the East side of the Tejo River, near the Carregueira village (see Fig. 8 for location). Note the fine upward sequence of the deposit, typical of this terrace level.

$>25 \mathrm{~m}$ thick unit of cross-bedded medium sands of fluvial origin.

\section{Optically stimulated luminescence dating}

Optically stimulated luminescence dating is a technique that measures the time that has elapsed since sedimentary grains of quartz or feldspar were last exposed to daylight (for a recent review of applications see Duller, 2004). Lightproof metal tubes were used for sampling sands and silts from sections located in the lower terraces (T5, T4 and T3; see Figs. 5 and 8 for sampling locations). All further processing took place under subdued red light. Wet sieving was used to separate the $180-250 \mu \mathrm{m}$ grain size, which was then acid treated using $\mathrm{HCl}(10 \%)$ and $\mathrm{H}_{2} \mathrm{O}_{2}(10 \%)$ to remove carbonates and organic matter, respectively. Potassium feldspars $\left(<2.58 \mathrm{~g} / \mathrm{cm}^{3}\right)$ and quartz $\left(>2.58 \mathrm{~g} / \mathrm{cm}^{3}\right)$ were separated using a sodium polytungstate heavy liquid solution. Quartz grains were etched and purified by dissolving any remaining minerals in concentrated $\mathrm{HF}$ $(40 \%)$ for $45 \mathrm{~min}$. K-feldspars grains were etched in diluted HF $(10 \%)$ for $40 \mathrm{~min}$ to remove any contribution from external alpha radiation in the determination of the dose rate. Finally, $\mathrm{HCl}(10 \%)$ was used again on both quartz and $\mathrm{K}$-feldspar extracts to dissolve any remaining soluble fluorides.

Luminescence measurements were performed on a Risø TL/DA-15 reader (Bøtter-Jensen et al., 2003). Luminescence detection was filtered either by a UV band pass Hoya U340 filter (for quartz) or by a combination of Schott BG39, Corning 7-59 and Schott GG400 filters (for $\mathrm{K}$-feldspar). Large $(8 \mathrm{~mm})$ and small $(2 \mathrm{~mm})$ aliquots were used for quartz and feldspar measurements, respectively.

A single-aliquot regenerative (SAR)-dose procedure was applied to measure the equivalent dose $\left(D_{\mathrm{e}}\right)$ of quartz (Murray and Wintle, 2000), using a preheat of $260^{\circ} \mathrm{C}$ for $10 \mathrm{~s}$ and a cut-heat to $220^{\circ} \mathrm{C}$. The quartz grains were stimulated using blue LEDs $(470 \pm 30 \mathrm{~nm})$ for $40 \mathrm{~s}$ at a sample temperature of $125^{\circ} \mathrm{C}$. After the test dose measurement, the aliquots were optically bleached for $40 \mathrm{~s}$ at a sample temperature of $280^{\circ} \mathrm{C}$ to reduce recuperation (Murray and Wintle, 2003). The net signal was derived by integrating the first $0.8 \mathrm{~s}$ of stimulation minus a background from the last $4 \mathrm{~s}$.

The SAR protocol for K-feldspars used identical heat treatments $\left(250^{\circ} \mathrm{C}\right.$ for $\left.60 \mathrm{~s}\right)$ for both dose and test dose measurements (Auclair et al., 2003; Huot and Lamothe, 2003). The net signal was derived by integrating the first $2 \mathrm{~s}$ of stimulation minus a background from the last $10 \mathrm{~s}$. Optical stimulation was carried out with infrared diodes $(880 \mathrm{~nm})$ for $100 \mathrm{~s}$ at $50^{\circ} \mathrm{C}$.

Radionuclide concentrations were measured by highresolution gamma spectrometry (Murray et al., 1987). Representative subsamples were dried, homogenised, cast 
in wax and stored for at least 3 weeks to allow for the establishment of a secular equilibrium between ${ }^{226} \mathrm{Ra}$ and ${ }^{222} \mathrm{Rn}$. Conversion factors to calculate the dose rates employed the values given in the paper by Olley et al. (1996). For K-feldspar, the contribution from internal beta activity from ${ }^{40} \mathrm{~K}$ is based on an effective potassium content of $12.5 \pm 0.5 \%$ (Huntley and Baril, 1997). A contribution of the cosmic ray dose rates was calculated following Prescott and Hutton (1994).

The luminescence dating results are summarised in Tables 1 and 2. Quartz OSL could only be used for two samples (052225 and 052235) for the other samples the natural luminescence was close to the saturation level of the sensitivity corrected growth curve. IRSL dating of $\mathrm{K}$-feldspar was undertaken on 24 samples, including the two samples for which quartz OSL is considered to give reliable values. Recycling ratios were close to unity, both for quartz and for K-feldspar, indicating that the test dose signals successfully monitored any changes in luminescence sensitivity throughout the measurement sequence. Recuperation (expressed as a percentage of the sensitivity corrected natural luminescence) does not exceed $5 \%$ in any sample. Dose recovery tests (Murray and Wintle, 2003) were satisfactory for most samples, with an overall mean of the measured to given dose ratio varying between $1.10 \pm 0.03$ and $0.84 \pm 0.01$, suggesting that this SAR protocol is able to accurately determine laboratory doses prior to any heating of the sample.
When using K-feldspar, the age obtained by dividing the $D_{\mathrm{e}}$ by the dose rate is expected to underestimate the burial age because of anomalous fading (Aitken, 1998: Appendix D). Measurements were carried out on 140 aliquots, representing most of the samples, to determine the anomalous fading rate (' $g$ ' value). In all samples examined, this fading rate was found to be indistinguishable from a weighted average fading rate of $3.15 \pm 0.04 \%$ /decade $\left(t_{\mathrm{c}}=48 \mathrm{~h}\right)$. This in turn implies that these sediments contain a homogeneous mixture of $\mathrm{K}$-feldspars, and the effects of anomalous fading should be similar from one sample to another. This also means that sediments of similar deposition age should give similar luminescence ages, whether or not they are corrected for fading. Therefore, lateral correlation of coeval terraces, independent of the model used for fading correction, is justified. Anomalous fading corrections were made using the dose rate correction (DRC) model of Lamothe et al. (2003); this is thought to be the most relevant model for large equivalent doses when the natural signals do not lie in the linear part of the growth curve. Nevertheless, there is scepticism concerning the accuracy of ages obtained from sediments with uncorrected $D_{\mathrm{e}}$ values $>500 \mathrm{~Gy}$. In these cases, the DRC model puts the natural signals close to luminescence saturation, giving a minimum corrected $D_{\mathrm{e}}$ of about $1000 \mathrm{~Gy}$. These sediments are considered to have a burial age of $>300 \mathrm{ka}$. The following discussion always refers to fading corrected ages.

Table 1

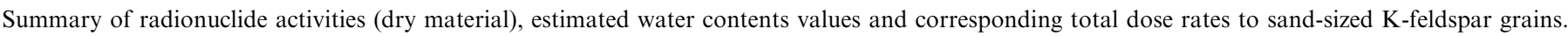

\begin{tabular}{|c|c|c|c|c|c|c|}
\hline Lab. code & ${ }^{238} \mathrm{U}(\mathrm{Bq} / \mathrm{kg})$ & ${ }^{226} \mathrm{Ra}(\mathrm{Bq} / \mathrm{kg})$ & ${ }^{232} \mathrm{Th}(\mathrm{Bq} / \mathrm{kg})$ & ${ }^{40} \mathrm{~K}(\mathrm{~Bq} / \mathrm{kg})$ & Water content $(\%)$ & Dose rate $(\mathrm{Gy} / \mathrm{ka})$ \\
\hline 052209 & $18 \pm 5$ & $17 \pm 0.5$ & $17 \pm 0.5$ & $727 \pm 13$ & 15 & $3.4 \pm 0.1$ \\
\hline 052210 & $28 \pm 6$ & $32 \pm 1.0$ & $28 \pm 0.9$ & $610 \pm 26$ & 19 & $3.4 \pm 0.1$ \\
\hline 052211 & $20 \pm 5$ & $14 \pm 0.4$ & $14 \pm 0.3$ & $839 \pm 12$ & 15 & $3.6 \pm 0.1$ \\
\hline 052236 & $17 \pm 6$ & $22 \pm 0.5$ & $26 \pm 0.6$ & $635 \pm 12$ & 15 & $3.4 \pm 0.1$ \\
\hline 052212 & $35 \pm 7$ & $37 \pm 0.6$ & $51 \pm 0.8$ & $730 \pm 13$ & 16 & $4.2 \pm 0.1$ \\
\hline 052240 & $40 \pm 6$ & $46 \pm 0.7$ & $70 \pm 0.8$ & $614 \pm 10$ & 10 & $4.6 \pm 0.2$ \\
\hline 052213 & $43 \pm 10$ & $63 \pm 2.0$ & $100 \pm 2.0$ & $881 \pm 36$ & 20 & $5.4 \pm 0.2$ \\
\hline 052214 & $57 \pm 7$ & $70 \pm 0.9$ & $107 \pm 1.0$ & $847 \pm 15$ & 17 & $5.8 \pm 0.2$ \\
\hline 052226 & $30 \pm 7$ & $29 \pm 0.6$ & $41 \pm 0.7$ & $736 \pm 12$ & 15 & $4.2 \pm 0.2$ \\
\hline 052235 & $11 \pm 4$ & $15 \pm 0.3$ & $15 \pm 0.3$ & $790 \pm 10$ & 12 & $3.6 \pm 0.1$ \\
\hline 052225 & $20 \pm 5$ & $19 \pm 0.5$ & $26 \pm 0.6$ & $968 \pm 15$ & 12 & $3.5 \pm 0.2$ \\
\hline 062204 & $40 \pm 6$ & $49 \pm 0.7$ & $43 \pm 0.7$ & $605 \pm 12$ & 14 & $3.9 \pm 0.1$ \\
\hline 062206 & $19 \pm 3$ & $16 \pm 0.3$ & $25 \pm 0.4$ & $285 \pm 5$ & 8 & $2.5 \pm 0.1$ \\
\hline 062207 & $45 \pm 5$ & $38 \pm 0.6$ & $57 \pm 0.7$ & $752 \pm 12$ & 10 & $4.7 \pm 0.2$ \\
\hline 062208 & $32 \pm 5$ & $25 \pm 0.5$ & $27 \pm 0.6$ & $822 \pm 13$ & 14 & $4.0 \pm 0.1$ \\
\hline 062218 & $16 \pm 3$ & $12 \pm 3.0$ & $17 \pm 3.0$ & $744 \pm 9$ & 8 & $3.6 \pm 0.1$ \\
\hline 062219 & $39 \pm 4$ & $34 \pm 0.4$ & $63 \pm 0.7$ & $753 \pm 10$ & 16 & $4.5 \pm 0.2$ \\
\hline 062220 & $28 \pm 4$ & $23 \pm 0.4$ & $39 \pm 0.5$ & $748 \pm 9$ & 11 & $4.1 \pm 0.1$ \\
\hline 062221 & $31 \pm 5$ & $32 \pm 0.5$ & $51 \pm 0.6$ & $595 \pm 8$ & 7 & $4.1 \pm 0.1$ \\
\hline 062222 & $17 \pm 4$ & $16 \pm 0.4$ & $14 \pm 0.4$ & $751 \pm 12$ & 7 & $3.6 \pm 0.1$ \\
\hline 062223 & $18 \pm 4$ & $22 \pm 0.4$ & $29 \pm 0.4$ & $1032 \pm 11$ & 10 & $4.7 \pm 0.2$ \\
\hline 062224 & $12 \pm 2$ & $12 \pm 0.2$ & $15 \pm 0.2$ & $1043 \pm 9$ & 6 & $4.5 \pm 0.2$ \\
\hline 062225 & $9 \pm 5$ & $13 \pm 0.4$ & $12 \pm 0.4$ & $1022 \pm 16$ & 6 & $4.3 \pm 0.2$ \\
\hline 062226 & $13 \pm 5$ & $17 \pm 0.4$ & $18 \pm 0.5$ & $989 \pm 15$ & 5 & $4.5 \pm 0.2$ \\
\hline
\end{tabular}


Table 2

Summary of dose recovery tests (minimum three aliquots per sample), $D_{\mathrm{e}}$ values, total dose rates and luminescence ages for K-feldspar IRSL and quartz (Qz) OSL.

\begin{tabular}{|c|c|c|c|c|c|c|c|c|c|c|c|}
\hline Lab code & Site name & $\begin{array}{l}\text { Tejo } \\
\text { reach }\end{array}$ & $\begin{array}{l}\text { Altit. } \\
(\mathrm{m})\end{array}$ & $\begin{array}{l}\text { Terrace } \\
\text { level }\end{array}$ & Grain size & $\begin{array}{l}\text { Dose } \\
\text { recovery }\end{array}$ & $D_{\mathrm{e}}(\mathrm{Gy})$ & $N$ & $\begin{array}{l}\text { Total dose } \\
\text { rate } \\
(\mathrm{Gy} / \mathrm{ka})\end{array}$ & Age (ka) & $\begin{array}{l}\text { Fading } \\
\text { corrected } \\
\text { age }(\mathrm{ka})\end{array}$ \\
\hline 052209 & Pego & III & 88 & T3 top & Coarse sand & $0.97 \pm 0.05$ & $563 \pm 17$ & 11 & $3.4 \pm 0.1$ & $165 \pm 8$ & $312 \pm 19$ \\
\hline 052210 & Casa Branca & III & 59 & T3 base & Sand very coarse & $0.96 \pm 0.011$ & $633 \pm 17$ & 12 & $3.4 \pm 0.1$ & $185 \pm 9$ & - \\
\hline 052211 & Pego & III & 80 & T3 base & Coarse sand & $0.97 \pm 0.01$ & $588 \pm 10$ & 14 & $3.6 \pm 0.1$ & $164 \pm 7$ & $311 \pm 17$ \\
\hline 052236 & Tancos & III & 61 & T3 middle & Coarse sand & $1.02 \pm 0.02$ & $585 \pm 24$ & 2 & $3.4 \pm 0.1$ & $171 \pm 10$ & - \\
\hline 052226 & Alvega & III & 60 & T5 middle & Medium sand & $0.93 \pm 0.01$ & $242 \pm 4$ & 18 & $4.2 \pm 0.2$ & $57 \pm 3$ & $85 \pm 3$ \\
\hline 052225 & Alvega & III & 62 & T5 top & $\begin{array}{l}\text { Medium } \\
\text { sandstone }\end{array}$ & not done & $122 \pm 1$ & 6 & $4.4 \pm 0.2$ & $28 \pm 1$ & $42 \pm 2$ \\
\hline 052225 (Qz) & Alvega & III & 62 & T5 top & $\begin{array}{l}\text { Medium } \\
\text { sandstone }\end{array}$ & $1.10 \pm 0.03$ & $151 \pm 6$ & 21 & $3.5 \pm 0.2$ & $43 \pm 3$ & \\
\hline 052212 & $\begin{array}{l}\text { Ponte } \\
\text { Mouriscas }\end{array}$ & III & 76 & $\mathrm{~T} 4$ top & Very fine sand & $0.95 \pm 0.002$ & $423 \pm 12$ & 16 & $4.2 \pm 0.1$ & $100 \pm 5$ & $160 \pm 9$ \\
\hline 052235 & Qtạ Lobão & III & 39.5 & T5 top & Coarse sand & not done & $150 \pm 3$ & 12 & $3.6 \pm 0.1$ & $41 \pm 2$ & $59 \pm 2$ \\
\hline 052235(Qz) & Qtạ Lobão & III & 39.5 & T5 top & Coarse sand & not done & $162 \pm 9$ & 27 & $2.8 \pm 0.1$ & $55 \pm 4$ & \\
\hline 052213 & Alferrarede & III & 43 & T5 middle & Medium sand & $1.06 \pm 0.02$ & $297 \pm 7$ & 12 & $5.4 \pm 0.2$ & $55 \pm 3$ & $96 \pm 5$ \\
\hline 052214 & Alferrarede & III & 46 & T5 top & Fine sand & $0.97 \pm 0.01$ & $269 \pm 6$ & 12 & $5.8 \pm 0.2$ & $46 \pm 2$ & $76 \pm 4$ \\
\hline 062208 & Constância & III & 47 & T4 base & Coarse sandstone & $0.84 \pm 0.01$ & $434 \pm 7$ & 12 & $4.0 \pm 0.1$ & $107 \pm 5$ & $190 \pm 15$ \\
\hline 052240 & Entroncamento & IV & 27 & T5 top & Silt & $0.96 \pm 0.004$ & $309 \pm 7$ & 12 & $4.6 \pm 0.2$ & $68 \pm 3$ & $99 \pm 6$ \\
\hline 062204 & $\begin{array}{l}\text { Vila Nova } \\
\text { Barquinha }\end{array}$ & IV & 59 & T4 middle & $\begin{array}{l}\text { Medium } \\
\text { sandstone }\end{array}$ & $0.99 \pm 0.01$ & $439 \pm 11$ & 12 & $3.9 \pm 0.1$ & $112 \pm 5$ & $169 \pm 9$ \\
\hline 062206 & Atalaia & IV & 57 & T4 middle & $\begin{array}{l}\text { Medium } \\
\text { sandstone }\end{array}$ & $0.92 \pm 0.01$ & $289 \pm 4$ & 12 & $2.5 \pm 0.1$ & $115 \pm 5$ & $172 \pm 6$ \\
\hline 062207 & $\begin{array}{l}\text { Courelas } \\
\text { (Golegã) }\end{array}$ & IV & 27 & T5 top & Fine sandstone & $1.01 \pm 0.01$ & $163 \pm 5$ & 11 & $4.7 \pm 0.2$ & $35 \pm 2$ & $51 \pm 3$ \\
\hline 062218 & Mato Mirandal & IV & 42 & T4 top & Coarse sandstone & $0.99 \pm 0.001$ & $431 \pm 10$ & 12 & $3.6 \pm 0.1$ & $119 \pm 6$ & $210 \pm 12$ \\
\hline 062219 & Mato Miranda2 & IV & 43 & T4 top & Fine sandstone & $0.99 \pm 0.002$ & $555 \pm 15$ & 12 & $4.5 \pm 0.2$ & $124 \pm 6$ & $222 \pm 18$ \\
\hline 062220 & Chamusca2 & IV & 101 & T3 top & $\begin{array}{l}\text { Medium } \\
\text { sandstone }\end{array}$ & $1.01 \pm 0.01$ & $576 \pm 19$ & 12 & $4.1 \pm 0.1$ & $141 \pm 7$ & - \\
\hline 062221 & $\begin{array}{l}\text { Pinheiro } \\
\text { Grande }\end{array}$ & IV & 90 & T4 top & $\begin{array}{l}\text { Medium } \\
\text { sandstone }\end{array}$ & $0.94 \pm 0.01$ & $357 \pm 10$ & 12 & $4.1 \pm 0.1$ & $87 \pm 4$ & $139 \pm 7$ \\
\hline 062222 & Chamuscal & IV & 86 & T3 base & Coarse sandstone & $0.97 \pm 0.04$ & $581 \pm 10$ & 12 & $3.6 \pm 0.1$ & $161 \pm 7$ & $292 \pm 14$ \\
\hline 062223 & Chamusca4 & IV & 39 & $\mathrm{~T} 4$ & $\begin{array}{l}\text { Medium } \\
\text { sandstone }\end{array}$ & $1.00 \pm 0.01$ & $350 \pm 6$ & 12 & $4.7 \pm 0.2$ & $75 \pm 3$ & $124 \pm 6$ \\
\hline 062224 & Chamusca5 & IV & 54 & $\mathrm{~T} 4$ top & $\begin{array}{l}\text { Medium } \\
\text { sandstone }\end{array}$ & $0.86 \pm 0.10$ & $319 \pm 7$ & 12 & $4.5 \pm 0.2$ & $70 \pm 3$ & $125 \pm 7$ \\
\hline 062225 & Chamusca6 & IV & 50 & T4 base & $\begin{array}{l}\text { Medium } \\
\text { sandstone }\end{array}$ & $0.98 \pm 0.004$ & $272 \pm 4$ & 11 & $4.3 \pm 0.2$ & $62 \pm 3$ & $107 \pm 5$ \\
\hline 062226 & Chamusca3 & IV & 38 & T5 top & $\begin{array}{l}\text { Medium } \\
\text { sandstone }\end{array}$ & $0.87 \pm 0.01$ & $133 \pm 2$ & 12 & $4.5 \pm 0.2$ & $30 \pm 1$ & $42 \pm 2$ \\
\hline
\end{tabular}

The fading corrected ages were calculated using the DRC model of Lamothe et al. (2003) and using a $g$ value of $3.15 \pm 0.04 \% /$ decade $\left(t_{\mathrm{c}}=2\right.$ days). For the $\mathrm{T} 3$ terrace, ages are considered as minimum estimates. See text for additional details.

\section{Terrace correlation between reaches III (upstream) and IV (downstream)}

The samples collected on the T3 terrace in reach III (Casa Branca - 052210; Pego top-052209; Pego base052211; and Tancos-052236) all gave a $D_{\mathrm{e}}>550 \mathrm{~Gy}$ and are assigned an age $>300 \mathrm{ka}$ (Table 2). Similarly, in reach IV, the Chamusca-1 (062222; T3 base) and Chamusca-2 (062220; T3 top) samples also provided similar minimum ages (Figs. 10, 12 and Table 2). Therefore, a stratigraphic correlation is suggested between the T3 terrace in reaches III and IV. The T3 terrace tread at $90-110 \mathrm{~m}$ a.s.l. in the Chamusca area along the eastern side of reach IV can be correlated with the $59 \mathrm{~m}$ a.s.l. terrace tread at Fonte da Serra along the western side of reach IV (Figs. 8 and 9).
Downstream, along reach III, the altitude of the T3 surface decreases (Figs. 5, 8 and 10): Pego ( $\sim 88 \mathrm{~m}$ a.s.1.), Tramagal $(\sim 83 \mathrm{~m})$, Tancos $(\sim 65 \mathrm{~m})$. However, along the eastern side of reach IV the elevation increases downstream, opposite to the natural slope of the river: Arripiado $(\sim 80 \mathrm{~m})$, Carregueira $(\sim 97 \mathrm{~m})$ and Chamusca $(\sim 100 \mathrm{~m})$. This is related to the uplifted block controlled by the Chamusca, Ulme and the Pai Poldro faults.

The ages obtained in the terrace level immediately below the Meia Via plateau, at Atalaia (55 m a.s.1.) and Mato Miranda ( $49 \mathrm{~m}$ a.s.1.) (reach IV), are similar to the T4 ages of reach III, described as follows.

In the T4 terrace of reach III, one sample was collected from the top (Ponte Mouriscas-052212; Fig. 5) and one from the base (Constância-062208; Fig. 8). The ages of these samples are $160 \pm 9$ and $190 \pm 15 \mathrm{ka}$, respectively. 
In the T4 terrace of the western side of reach IV, ages were obtained between $169 \pm 9$ and $222 \pm 18$ ka (see Fig. 9; Vila Nova da Barquinha-062204, Atalaia-062206, Mato Miranda1-062218 and Mato Miranda2-062219).

On the eastern side of reach IV (Fig. 10), the T4 terrace at $75 \mathrm{~m}$ a.s.l. was dated to $139 \pm 7 \mathrm{ka}$ (sample 062221 ); the T4a top at $40-50 \mathrm{~m}$ a.s.l. gives ages of $124 \pm 6 \mathrm{ka}$ (sample 062223 ), $125 \pm 7 \mathrm{ka}$ (sample 062224) and $107 \pm 5 \mathrm{ka}$ (sample 062225).

In the Tancos-Constância area, the headward-eroding of a small stream piracy the Zêzere River near the mouth, leaving an abandoned valley at the altitude of the terrace T4 of the Tejo River (Fig. 8). Taking in account the geomorphic position of the abandoned valley and the ages of the T4 and T5 terraces, the piracy should have occurred just after the final aggradation of the $\mathrm{T} 4$ terrace and before the formation of the T5 terrace: not earlier than $\sim 100 \mathrm{ka}$.

The samples collected from the T5 terrace in reach III give ages consistent with the stratigraphic position of the samples in the terrace sequence. At the Alvega depression, sample $052226(85 \pm 3 \mathrm{ka})$ was collected from a sandstone above the basal conglomerate of the terrace and the sample $052225 \mathrm{Qz}(43 \pm 3 \mathrm{ka})$ from sands at the top. At Alferrarede, sample $052213(96 \pm 5 \mathrm{ka})$ was collected just above the T5 basal conglomerate and sample $052214(76 \pm 4 \mathrm{ka}) 2 \mathrm{~m}$ above this horizon. Sample 052235, taken from the top of T5 at Quinta do Lobão, was dated both with K-feldspar $(59 \pm 2 \mathrm{ka})$ and quartz $(55 \pm 4 \mathrm{ka})$; these ages are indistinguishable.

In reach IV, two samples were collected $5 \mathrm{~km}$ apart from the top of the T5 terrace: $052240(99 \pm 6 \mathrm{ka})$ and 062207
$(51 \pm 3 \mathrm{ka})$. They are significantly different but still in the age range obtained for the $\mathrm{T} 5$ in reach III. The difference in age of samples collected close to the same terrace surface could be the result of the progressive lateral migration of the river. Sample $062226(42 \pm 2 \mathrm{ka})$ was collected from the top of T5 close to the Chamusca scarp, on the eastern side of the valley (Figs. 8 and 10); this K-feldspar age is indistinguishable from the quartz age of sample 052225 $(43 \pm 3 \mathrm{ka})$ collected from the top of T5 in the Alvega depression (reach III, Fig. 5). The minimal age of the top of T5 is well established both in reaches III and IV. Considering the youngest age of the $\mathrm{T} 4$ aggradation $(107 \pm 5 \mathrm{ka})$ and the time necessary for the following incision episode, the $\mathrm{T} 5$ deposits are younger than $\sim 100 \mathrm{ka}$ and older than $\sim 40 \mathrm{ka}$.

In Fig. 12 luminescence ages for the terraces are plotted against the distance to the river mouth, comprising the above presented ages of terraces belonging to reaches IV and III, but also ages obtained in reach I by Cunha et al. (2008). The T4 age range in reach IV is similar to the range observed in reach I, suggesting that $\mathrm{T} 4$ is younger than $\sim 280 \mathrm{ka}$ and older than $\sim 105 \mathrm{ka}$. The T5 ages obtained in the reaches IV and III range from $\sim 99$ to $\sim 42 \mathrm{ka}$, but in reach I they lie between $\sim 39$ and $\sim 32 \mathrm{ka}$.

An interesting aspect arises from the comparison of the probable duration of the aggradation and incision episodes. The duration of the incision episode following the final aggradation of the $\mathrm{T} 4$ was longer in reach I (located at least $45 \mathrm{~km}$ upstream) than in reaches III and IV. The duration of the downcutting following the cessation of T4 aggradation is surprisingly short in reach

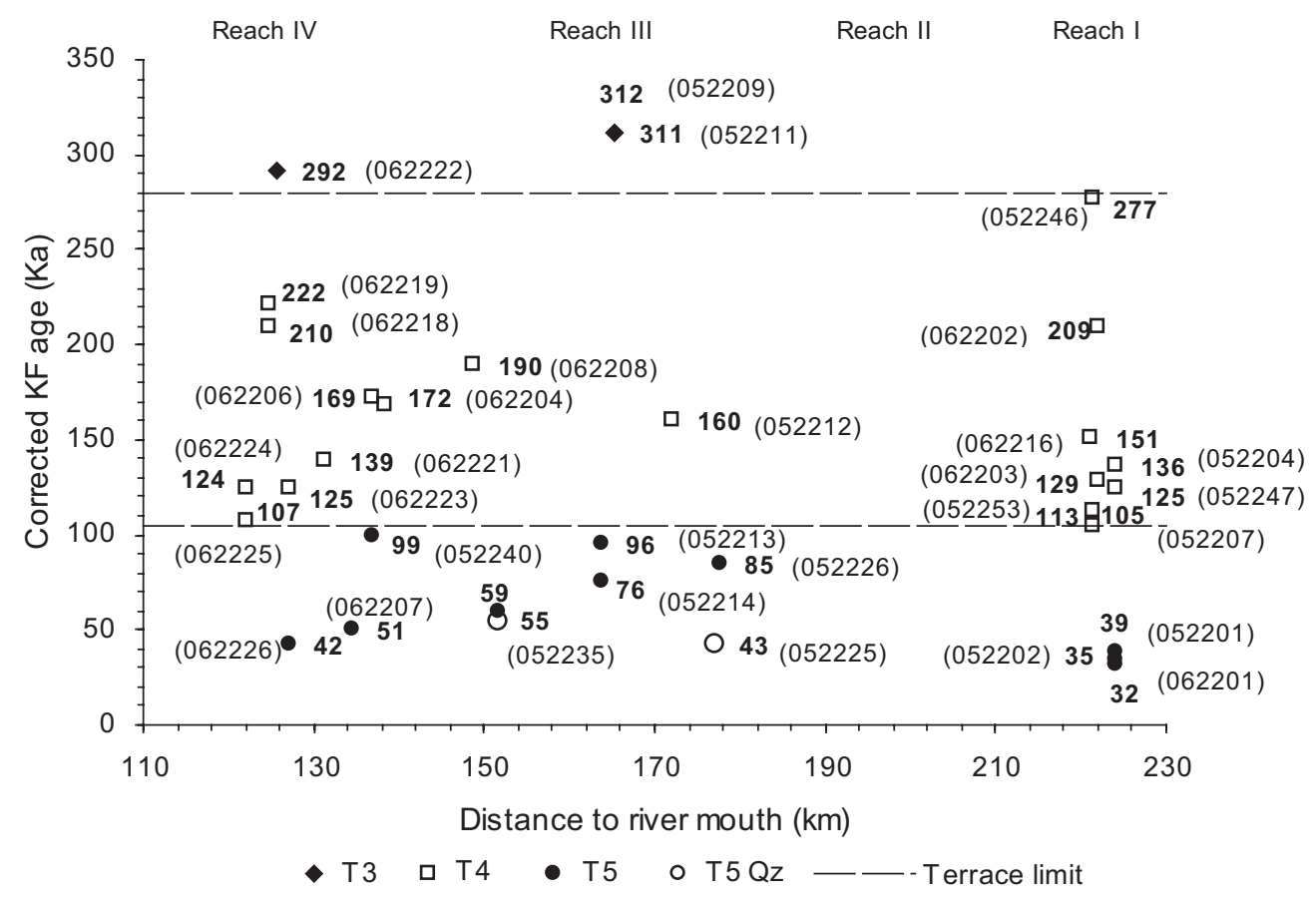

Fig. 12. Ages of the terraces (T3, T4 and T5) plotted against the distance to the Tejo River mouth (reaches I, III and IV). As previously discussed, the T3 K-feldspar ages should be considered as minimal. Diamond-shaped-T3 K-feldspar ages; squares-T4 K-feldspar ages; circles-T5 K-feldspar ages; open circles-T5 Quartz ages. Ages of reach I, according to Cunha, et al. (2008). 
IV (probably $<8 \mathrm{ka}$; $\sim 107-99 \mathrm{ka}$ ), while the following aggradation period of the T5 is $\sim 57 \mathrm{ka}(\sim 99-42 \mathrm{ka})$. The opposite seems to happen in reach I, upstream, where the incision is longer ( $\sim 66 \mathrm{ka}, \sim 105-39 \mathrm{ka})$ than the following aggradation $(\sim 7 \mathrm{ka}, \sim 39-32 \mathrm{ka})$. The differential onset of timing for the incision of the T4 terrace between reach I and the reaches III and IV could be related to a tectonically driven incision wave passing upstream through time. The discrepancy is likely not related to a delay in the aggradation post-incision times, but to a delay in the incision prior to the aggradation of the T5 terrace. This is consistent with the differential time-response of fluvial systems to the changes of external controls (Humphrey and Heller, 1995). The discrepancy of the timing for the incision of the T5, referred to above, can also be related to the lithology. In reaches III and IV the incision of the T5 terrace was done in soft Tertiary sediments, while in reach I the incision was done in the hard Palaeozoic basement. In reaches III and IV, $\sim 8 \mathrm{ka}(\sim 107-99 \mathrm{ka})$ was the period of the incision, following the abandonment of terrace T4 surface; a brief time interval compared with the earlier period $\sim 170 \mathrm{ka}(\sim 277-107 \mathrm{ka})$ of predominantly lateral planation and strath terrace formation. The brief periods of incision and the apparently long periods of lateral planation corroborate the experimental results obtained by Hancock and Anderson (2002), in a numerical modelling of strath terrace formation.

Sea-level changes seem not to have been the driving force of the incision in reaches III and IV (Cunha et al., 2005), in spite of these reaches being downstream of reach I. The sea-level changes driven by climatic changes have temporal scales $<10^{4}$ years (Blum and Törnqvist, 2000), very different from the overall $\mathrm{T} 4$ aggradation time. The incision interval between T4 and T5 comprise the sea-level high stand of the oxygen isotope stage MIS 5c (e.g. Pillans et al., 1998; Shackleton et al., 2003). Therefore, this incision has been mainly controlled by a regional uplift event (tectonic phase). The important sea-level low of MIS 6 , which occurred at $\sim 140 \mathrm{ka}$ when the sea level was at about $-120 \mathrm{~m}$, is not identifiable in the T4 deposits, always showing a similar fining upwards sequence. The influence of climate was also not detected at this scale of analysis.

\section{Local tectonics affecting geomorphic references}

The Gavião and Ortiga faults are recognized by the presence of vertical offsets in the river valley. Lack of terrace deposits upstream of these faults (Fig. 9) prevented luminescence dating. The Gavião and Ortiga faults clearly displaced the CSS and the T1 and T2 terraces, but these terraces are poorly represented. The Ortiga fault does not seem to have been active after the formation of the T3 (last $300 \mathrm{ka}$ ), whereas the Gavião fault induced a vertical offset of $\sim 20 \mathrm{~m}$ in the $\mathrm{T} 3$ terrace.

The influence of tectonics can also be documented in the Alvega depression (Figs. 5 and 10). The terraces inside this depression (T5: $\sim 45 \mathrm{~m}, \mathrm{~T} 4: \sim 66 \mathrm{~m}, \mathrm{~T} 3: \sim 88 \mathrm{~m}$ a.s.1.) are less elevated than in the area immediately downstream (T5: $\sim 55 \mathrm{~m}, \mathrm{~T} 4: \sim 85 \mathrm{~m}, \mathrm{~T} 3: \sim 105 \mathrm{~m}$ a.s.l.). In addition, the T3 is only $\sim 10 \mathrm{~m}$ thick outside of the depression, but $\sim 30 \mathrm{~m}$ thick inside, suggesting tectonic subsidence synchronous with the sedimentation.

The Rio Torto fault induced a vertical displacement of the T3 terrace (Fig. 10). The main geomorphic evidence for tectonics affecting terrace development is observed downstream, caused by the Vila Nova da Barquinha and Arripiado-Chamusca faults (Figs. 8 and 9).

On the western side of reach IV, from Vila Nova da Barquinha towards Azinhaga, the terraces converge downstream and T5 disappears below the modern alluvium (Fig. 9). This contrasts with the eastern side of the valley where the CSS and the higher terraces (T1, T2 and T3) are converging upstream (Fig. 10), because of their location on the Chamusca block, which is uplifted and tilted to the northeast; this deformation probably produced the duplication of the T4 near the Ulme stream.

A transverse survey of the river valley at Chamusca shows the same geomorphic references, but more elevated on the upthrusted block of the Arripiado-Chamusca fault (Table 3, Fig. 8). For example, the T1 terrace is $\sim 95 \mathrm{~m}$ a.s.1. at the Chões, Bica and Charneca "mesas" but $\sim 150 \mathrm{~m}$ a.s.l. at Chamusca; the T3 terrace is at $\sim 59 \mathrm{~m}$ a.s.l. at Fonte da Serra but at $\sim 89 \mathrm{~m}$ a.s.l. at Chamusca; the T4 terrace is at $\sim 42 \mathrm{~m}$ a.s.l. at Mato Miranda but at $\sim 75 \mathrm{~m}$ a.s.l. at Chamusca.

Table 3

Terrace altitudes at the west and east sides of Tejo (reach IV).

\begin{tabular}{lllll}
\hline & $\begin{array}{l}\text { Elevation of west side } \\
\text { terraces }(\mathrm{m})\end{array}$ & $\begin{array}{l}\text { Height above the modern } \\
\text { alluvial plain }(\mathrm{m})\end{array}$ & $\begin{array}{l}\text { Elevation of east side } \\
\text { terraces (m) }\end{array}$ & $\begin{array}{l}\text { Height above the modern } \\
\text { alluvial plain }(\mathrm{m})\end{array}$ \\
\hline CSS (Pliocene) & - & - & 190 & 174 \\
T1 & $93-100$ & 84 & $148-154$ & $132-138$ \\
T2 & 73 & 57 & $120-128$ & $104-112$ \\
T3 & 59 & 43 & 89 & 73 \\
T4 & 42 & 26 & 75 & 59 \\
T5 & $24 / 18$ & $8-2$ & 27 & 11 \\
Alluvial plain & $\sim 16$ & - & 16 & - \\
\hline
\end{tabular}

Vertical tectonic displacements between the east and the west side terraces were calculated using the modern alluvial plain as a common reference. 


\section{Estimation of time-averaged incision rates}

The height of terrace surfaces above a modern river bed is often used to calculate incision rates (Maddy, 1997; Maddy et al., 2000). These can then be used as a proxy for rock-uplift rates (Merritts et al., 1994). The regional framework of the Tejo River is influenced by regional patterns of uplift and local movements along individual structures, and this complicates the calculation of time average uplift rates. As reach IV and part of reach III were flooded and backfilled during the Holocene transgression, there is some uncertainty if the steady state profile has been fully reached. An additional uncertainty is associated with the ages corrected for the effects of anomalous fading, which means that one should be cautious when proposing uplift rates.

Incision rates can be calculated by dividing the height of the terrace above the modern river bed surface by its age. For the terrace staircase of Alvega (reach III), the levels of the samples $052225 \quad(43 \pm 3 \mathrm{ka}, 18 \mathrm{~m}$ a.r.b), 052212 $(160 \pm 9 \mathrm{ka}, 47 \mathrm{~m}$ a.r.b.), were used as the surfaces of the T5 and T4 terraces. At Abrantes, the reference for the T5 terrace was sample 052214 (76 $\pm 4 \mathrm{ka}, 24 \mathrm{~m}$ a.r.b.), and for the T4 surface (50 m a.r.b.) sample $052212(160 \pm 9 \mathrm{ka})$ was used because the two staircases are adjacent. In these two staircases of reach III (Figs. 13 and 14), the CSS (top of the Serra de Almeirim Conglomerates, about $200 \mathrm{~m}$ a.s.l., $171 \mathrm{~m}$ a.r.b.) is considered to have an estimated age of 2.6 Ma, based upon dating in the more distal sediments of this Atlantic sedimentary system (Cunha et al., 1993).

For the Alvega staircase, time-averaged incision rates were estimated as follows: (a) $\sim 0.42 \mathrm{~m} / \mathrm{ka}$ over the last $\sim 43 \mathrm{ka}(18 \mathrm{~m} / 43 \mathrm{ka}) ;(\mathrm{b}) \sim 0.29 \mathrm{~m} / \mathrm{ka}$ over the last $\sim 160 \mathrm{ka}$ $(47 \mathrm{~m} / 160 \mathrm{ka})$. For the Abrantes staircase, time-averaged incision rates were estimated as follows: (a) $\sim 0.32 \mathrm{~m} / \mathrm{ka}$ over the last $\sim 76 \mathrm{ka}(24 \mathrm{~m} / 76 \mathrm{ka}) ;$ (b) $\sim 0.31 \mathrm{~m} / \mathrm{ka}$ over the last $\sim 160 \mathrm{ka}(50 \mathrm{~m} / 160 \mathrm{ka})$. The decrease in the timeaveraged incision rate in longer time-scales is probably more apparent than real. For the T5 terrace the incision rate is averaged over a period of almost continual incision (since the abandonment of the T5 terrace surface, until the modern river bed formation), while for the $\mathrm{T} 4$ terrace, the incision rate is averaged also for the long period of lateral planation.

The amount of dissection by the Tejo River provides a relative approximation of the different uplift between individual structures. In reach II, upstream of the Gavião fault and at crossing the Gavião and the Ortiga faults, the vertical dissection from the CSS to the modern river bed is $\sim 230 \mathrm{~m}$. This dissection decreases to $\sim 160 \mathrm{~m}$ in reach III and to $\sim 140 \mathrm{~m}$ at the Vila Nova da Barquinha fault, in the eastern side of reach IV.

Taking the T3 and the modern alluvial plain as geomorphic references, the dissections are as follows: $\sim 62 \mathrm{~m}$ at Tancos $(82-20 \mathrm{~m}) ; \sim 74 \mathrm{~m}$ at Chamusca (89-15 m) and only $\sim 41 \mathrm{~m}(55-14 \mathrm{~m})$ west of Mato Miranda. The differences in dissection should correspond to differ-

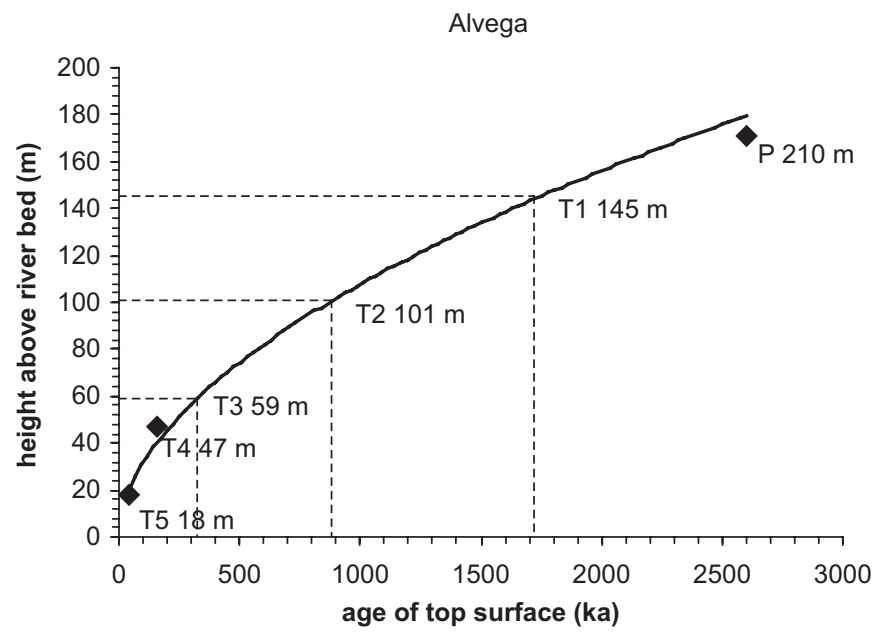

Fig. 13. For the Alvega terrace staircase, ages of the T5, T4 and Serra the Almeirim Conglomerates top ( $\mathrm{P}$; probable age) are plotted against the height above river bed. The ages of $\mathrm{T} 3, \mathrm{~T} 2$ and $\mathrm{T} 1$ were estimated by extrapolation.

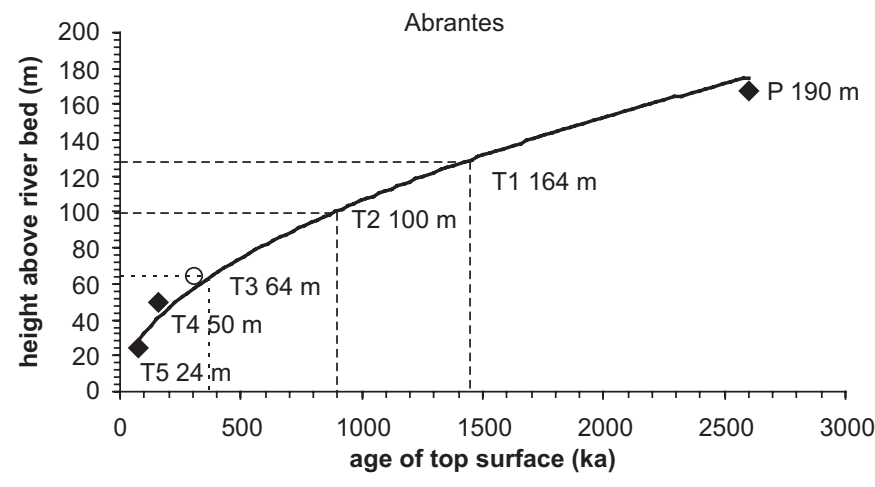

Fig. 14. For the Abrantes terrace staircase, ages of the T5, T4 and Serra the Almeirim Conglomerates top ( $\mathrm{P}$; probable age) plotted against the height above river bed. The ages of T3, T2 and T1 were roughly estimated by extrapolation. Note that the two minimal ages obtained in the T3 terrace of this staircase (open circles) are not very different from the value found by extrapolation $(\sim 365 \mathrm{ka})$.

ential uplift among the structures of Vila Nova da Barquinha and Arripiado-Chamusca. An estimate for the age of the T3, T2 and T1 top deposits was obtained by fitting a curve using the available age controls and the respective heights of terrace surfaces above river bed. Extrapolating this, a simple relationship with an age probably between $\sim 325$ and $380 \mathrm{ka}$ is found for the T3 terrace, consistent with the obtained K-feldspar ages suggesting a minimum burial age of $\sim 300 \mathrm{ka}$.

\section{Conclusions}

The general geomorphological characteristics in reach III of the Tejo River are defined by an E-W alignment of three depressions (Alvega, Rossio and Tramagal), containing soft Tertiary sediments, and hard basement blocks, crossed by the river (superimposed). The basement blocks 
located at the downstream end of the depressions have acted as local base levels. These have contributed to the enlargement of the upstream valley and promoted the development of terraces within the depressions, due to the combination of the river widening and gradient decrease. This is in contrast to the narrow valleys cut in the basement. Although a set of highs and lows have been exposed by exhumation during the incision stage, tectonic activity continued to emphasise the morphology. In reach IV, the morphotectonic features change significantly at the intersection of the Vila Nova da Barquinha fault with the Arripiado-Chamusca fault.

Some faults affected the probable Piacenzian deposits of the Tejo River. Those pre-dating the incision stage and displacing the terraces were found to be active up to the present day. The most important fault systems, trending WNW-ESE (Gavião and Vila Nova da Barquinha) and NNE-SSW (Arripiado-Chamusca), were probably reactivated under regional WNW-ESE compression.

Although some faults induced vertical displacements, it is possibly to correlate the terraces along the studied Tejo River valley. The $\mathrm{T} 1$ and $\mathrm{T} 2$ terraces are poorly represented whereas the $\mathrm{T} 3$ terrace constitutes a relatively continuous reference. The T4 and T5 terraces are only represented in tectonic depressions, in which the river excavated the soft Tertiary sediments. The wide extension of the T3 terrace even in areas with a hard bedrock points to long-term equilibrium conditions.

The high dose rates of the sediments $(3-5 \mathrm{~Gy} / \mathrm{ka})$ prevented the use of quartz OSL dating for nearly all samples. However, infrared stimulated luminescence dating of K-feldspar (with anomalous fading correction) has provided important support for the geomorphological correlation of the terraces. In spite of uncertainties associated with the fading correction procedure, this approach provided corrected K-feldspar ages similar to those obtained from non saturated quartz ages.

Within reaches III and IV of the Tejo, aggradation episodes occurred at: $\sim 42-99 \mathrm{ka}$ for T5, $\sim 107$ to $>222 \mathrm{ka}$ for T4 and $>300 \mathrm{ka}$ for T3. Periods of lateral planation and strath terrace formation were longer than the incision times. Tectonics seems to be the main driven mechanism, as the timing of changes from aggradation to downcutting does not match with significant climate or eustatic changes.

\section{Acknowledgments}

This work is within the scope of the project POCI/CTEGEX/58120/2004 "Fluvial terraces, references to evaluate the fluvial incision and crustal uplift in central Portugal (western Iberia)", approved by the Fundação para a Ciência e a Tecnologia and co-founded by the FEDER. Research was supported by the Centro de Geociências da Universidade de Coimbra, Departamento de Geociências da Universidade de Évora (Portugal) and Risø National Laboratory (Denmark). The authors would like to thank Nuno Gracinhas and João Matos for helping with the drawing in GIS. S.H. thanks the Joint Committee of the Nordic Natural Science Research Councils, through the Nordic Centre for Luminescence Research-NLL (a Nordic Centre of Excellence), for financial support. The visits of A.M. and P.C. to the NLL at Risø were supported by the Fundação para a Ciência e a Tecnologia (Sabbatical grants). We thank Martin Stokes, University of Plymouth, for the revision of the manuscript and useful comments.

\section{References}

Aitken, M., 1998. An introduction to optical dating. Oxford University Press, Oxford, 267pp.

Antunes, T., Pais, J., 1993. The Neogene of Portugal. Ciências da Terra $12,7-22$.

Auclair, M., Lamothe, M., Huot, S., 2003. Measurement of anomalous fading for feldspar IRSL using SAR. Radiation Measurements 37, 487-492.

Azevedo, T., 1991. Essais de reconstitution paléogéographique du basin de Lisbonne au Paléogène. Memórias e Notícias, Publications, Museum Laboratory of Mineralogy and Geology 112, 525-564.

Barbosa, B., 1995. Alostratigrafia e Litoestratigrafia das Unidades Continentais da Bacia Terciária do Baixo Tejo. Relações com o Eustatismo e a Tectónica. Ph.D. Thesis, University of Lisbon, 253pp.

Barbosa, B., Reis, P., 1989. Litostratigrafia e modelo deposicional dos sedimentos aluviais do Neogénico superior da bacia do Tejo (TomarLavre), Portugal. Comunicações dos Serviços Geológicos de Portugal 75, 89-97.

Barbosa, B., Reis, P., 1996. Geometrias de enchimento, sistemas deposicionais e organização estratigráfica do pliocénico continental da Bacia Terciária do Baixo Tejo (Portugal). Comunicações Instituto Geológico e Mineiro 82, 51-86.

Blum, D., Törnqvist, E., 2000. Fluvial responses to climate and sea-level change; a review and look forward. Sedimentology 47 (Suppl. 1), 2-48.

Bridgland, R., 2000. River terrace systems in north-west Europe: an archive of environmental change, uplift and early human occupation. Quaternary Science Reviews 19, 1293-1303.

Burbank, W., Anderson, S., 2001. Tectonic Geomorphology. Blackwell Science, 274pp.

Burbank, W., Meigs, A., Brozovic, N., 1996. Interactions of growing folds and coeval depositional systems. Basin Research 8, 199-223.

Bøtter-Jensen, L., Andersen, C., Duller, G., Murray, A., 2003. Developments in radiation, stimulation and observation facilities in luminescence measurements. Radiation Measurements 37, 535-541.

Cabral, J., 1995. Neotectónica de Portugal continental. Memoirs, Institute of Geology and Mineralogy of Portugal 31, 265pp.

Cabral, J., Ribeiro, P., Figueiredo, P., Pimentel, N., Martins, A., 2004. The Azambuja fault: an active structure located in an intraplate basin with significant seismicity (Lower Tagus Valley, Portugal). Journal of Seismology 8, 347-362.

Carvalho, G., Ribeiro, A., Cabral, J., 1983-1985. Evolução paleogeográfica da bacia cenozóica do Tejo-Sado. Boletim da Sociedade Geológica de Portugal XXIV, 209-212.

Cloetingh, S., Ziegler, A., Beekman, F., Andriessen, M., Matenco, L., Bada, G., Garcia-Castellanos, D., Hardebol, N., Dèzes, P., Sokoutis, D., 2005. Lithospheric memory, state of stress and rheology: neotectonic controls on Europe's intraplate continental topography. Quaternary Sciences Reviews 24, 241-304.

Cunha, P., 1992. Estratigrafia e sedimentologia dos depósitos do Cretácico Superior e Terciário de Portugal Central, a leste de Coimbra. Ph.D. Thesis, University of Coimbra, Portugal, 262pp.

Cunha, P., 1996. Unidades litostratigráficas do Terciário da Beira Baixa (Portugal). Comunicações Instituto Geológico e Mineiro 82, 87-130.

Cunha, P., Barbosa, B., Reis, P., 1993. Synthesis of the Piacenzian onshore record, between the Aveiro and Setúbal parallels (Western Portuguese margin). Ciências da Terra 12, 35-43. 
Cunha, P., Martins, A., Daveau, S., Friend, P., 2005. Tectonic control of the Tejo River fluvial incision during the late Cenozoic, in Ródão - central Portugal (Atlantic Iberian border). Geomorphology 64, 271-298.

Cunha, P., Martins, A., Huot, S., Murray, A., Raposo, L., 2008. Dating the Tejo River lower terraces (Ródão, Portugal) to assess the role of tectonics and uplift. Geomorphology 102, 43-54.

Duller, G., 2004. Luminescence dating of Quaternary sediments: recent advances. Journal of Quaternary Science 19, 183-192.

Fernandez, C., 1997. Secciones con material arqueológico en estrato en las proximidades de Atalaia. Interpretazione Geo-Archeologica di Alcune Industrie Litiche "Languedocensi" del Medio Bacino del Tejo. In: Cruz, A., Oosterbeek, L., Reis, P., (Eds.), Quaternário e Pré-Historia do Alto Ribatejo (Portugal). Ceiphar, Centro de Pré-História do Instituto Politécnico de Tomar, Arkeos 4, pp. 227-259.

Galdeano, S., 2000. Evolution of Ibéria during the Cenozoic with special emphasis on the formation of the betic cordillhera and its relation with the western Mediterranean. In: Cenozóico de Portugal (Ed.), Papers presented at the 1o Congresso sobre o Cenozoico de Portugal. Faculdade de Ciências e Tecnologia, Universidade Nova de Lisboa, pp. 5-19.

Grimaldi, S., Rosina, P., Fernandez, I., 1997. Interpretazione GeoArcheologica di Alcune Industrie Litiche "Languedocensi" del Medio Bacino del Tejo. In:, Cruz, A., Oosterbeek, L., Reis, P., (Eds.), Quaternário e Pré-Historia do Alto Ribatejo (Portugal). Ceiphar, Centro de Pré-História do Instituto Politécnico de Tomar, Arkeos 4, pp. 145-226

Gutiérrez-Elorza, M., 1994. Introduccion a la Geomorfologia Española. In: Gutierrez-Elorza, M. (Ed.), Geomorfología de España. Editorial Rueda, pp. 1-22.

Hancock, G., Anderson, R., 2002. Numerical modelling of fluvial strathterrace formation in response to oscillating climate. Geological Society of America Bulletin 114 (9), 1131-1142.

Humphrey, F., Heller, L., 1995. Natural oscillations in coupled geomorphic systems: an alternative origin for cyclic sedimentation. Geology 23, 499-502.

Huntley, D., Baril, M., 1997. The K content of the K-feldspars being measured in optical dating or thermoluminescence dating. Ancient TL $15,11-13$.

Huot, S., Lamothe, M., 2003. Variability of infrared stimulated luminescence properties from fractured feldspar grains. Radiation Measurements 37, 499-503.

Lamothe, M., Auclair, M., Hamzaoui, C., Huot, S., 2003. Towards a prediction of long-term anomalous fading of feldspar IRSL. Radiation Measurements 37, 493-498.

Maddy, D., 1997. Uplift-driven valley incision and river terrace formation in southern England. Journal of Quaternary Science 12 (6), 539-545.

Maddy, D., Bridgland, R., Green, P., 2000. Crustal uplift in southern England: evidence from the river terrace records. Geomorphology 33, 167-181.

Martins, A., 1999. Caracterização Morfotectónica e Morfossedimentar da Bacia do Baixo Tejo, Pliocénico e Quaternário. Ph.D. Thesis, Universidade de Évora, 500pp.

Martins, A., Barbosa, B., 1992. Planaltos do Nordeste da Bacia Terciária do Tejo (Portugal). Comunicações dos Serviços Geológicos de Portugal 78 (1), 13-22.
Mendes-Victor, A., Hirn, A., Veinante, L., 1980. A seismic section across the Tagus valley, Portugal: possible evolution of the crust. Annales Géophysique 36 (4), 469-476.

Merritts, J., Vicent, R., Wohl, E., 1994. Long river profiles, tectonism and eustasy: a guide to interpreting fluvial terraces. Journal of Geophysical Research 99 (B7), 14031-14050.

Murray, A., Marten, R., Johnston, A., Martin, P., 1987. Analysis for naturally occurring radionuclides at environmental concentrations by gamma spectrometry. Journal of Radioanalytical and Nuclear Chemistry $115,263-288$.

Murray, A., Wintle, A., 2000. Luminescence dating of quartz using an improved single-aliquot regenerative-dose protocol. Radiation Measurements $32,57-73$.

Murray, A., Wintle, A., 2003. The single aliquot regenerative dose protocol: potential for improvements in realiability. Radiation Measurements 37, 377-381.

Olley, J., Murray, A., Roberts, R., 1996. The effects of disequilibria in the uranium and thorium decay chains on burial dose rates in fluvial sediments. Quaternary Science Reviews (Quaternary Geochronology) 15, 751-760.

Pillans, P., Chapell, J., Naish, C., 1998. A review of the Milankovich climatic beat: template for Plio-Pleistocene sea-level changes and sequence stratigraphy. Sedimentary Geology 211, 5-12.

Prescott, R., Hutton, T., 1994. Cosmic ray contributions to dose rates for luminescence and ESR dating: large depths and long-term variations. Radiation Measurements 23, 497-500.

Raposo, L., 1995. Ambientes, territorios y subsistencia en el Paleolitico medio de Portugal. Complutum 6, 57-77.

Raposo, L., Cardoso, J., 1998. O Sítio do Paleolítico Médio da Conceição (Alcochete). Centro de Estudos e Monitorização Ambiental, 74pp.

Rasmussen, S., Lombolt, S., Andersen, C., Vejbaek, V., 1998. Aspects of the structural evolution of the Lusitanian Basin in Portugal and the shelf and slope area offshore Portugal. Tectonophysics 300, 199-225.

Ribeiro, A., Cabral, J., Baptista, R., Matias, L., 1996. Stress pattern in Portugal mainland and the adjacent Atlantic region, West Iberia. Tectonics 15, 641-659.

Ribeiro, A., Kullberg, C., Kullberg, C., Manuppella, G., Phipps, S., 1990. A review of Alpine tectonics in Portugal: foreland detachment in basement and cover rocks. Tectonophysics 184, 357-366.

Seidl, A., Dietrich, E., 1992. The problem of channel erosion into bedrock. Catena Supplement 23, 101-124.

Shackleton, N., Sanchez-Goñi, M., Pailler, D., Lancelot, Y., 2003. Marine Isotope Substage $5^{\mathrm{e}}$ and the Eemian Interglacial. Global and Planetary Change 36, 151-155.

Srivastava, P., Roest, R., Kovacs, C., Oakey, G., Lévesque, S., Verhoef, J., Macnab, R., 1990. Motion of the Iberia since the Late Jurassic: results from detailed aeromagnetic measurements in the Newfoundland Basin. Tectonophysics 184, 229-260.

Zbyszewski, G., 1946. Étude Geologique de la région d'Alpiarça. Comunicações dos Serviços Geológicos de Portugal 27, 145-268.

Zbyszewski, G., 1958. Le Quaternaire du Portugal. Boletim da Sociedade Geológica de Portugal 12, 1-227. 